\begin{tabular}{|l|l|l|l|l|l|}
\hline MUNIBE Antropologia-Arkeologia & $n^{\circ} 66$ & $23-52$ & DONOSTIA & 2015 & ISSN $1132-2217 \bullet$ elSSN $2172-4555$ \\
\hline
\end{tabular}

\title{
The Gravettian occupation of Level 4 at Cueva Morín (Cantabrian Region) and its regional context
}

\author{
La ocupación gravetiense del nivel 4 de Cueva Morín \\ (Región Cantábrica) y su contexto regional
}

PALABRAS CLAVES: Gravetiense, región cántabra, datación por radiocarbono, estudios líticos, movilidad. GAKO-HITZAK: Gravettiar, Kantabria eskualdea, Karbono-14 bidezko datazioa, azterketa litikoak, mugikortasuna. KEY WORDS: Gravettian, Cantabrian region, Radiocarbon Dating, Lithic studies, Mobility.

Marcel BRADTMÖLLER(1)

\section{RESUMEN}

Aunque el tecno-complejo gravetiense de la región cántabra y la comunidad de Cantabria en particular ha sido, durante mucho tiempo, una zona poco estudiada en la investigación del Paleolítico superior, una reciente investigación sobre este tema ha descubierto una gran variedad de tipos de asentamientos, amplios patrones de obtención de materias primas líticas y extensas conexiones con los Pirineos franceses. Lamentablemente, los estudios tecnológicos líticos todavía no son habituales, lo cual dificulta, junto un conjunto pequeño y poco representativo de datos de radiocarbono, la comprensión diacrónica y regional más profunda de la variabilidad observada. Por lo tanto, este estudio aporta nuevos datos para el modelo de edad y una descripción exhaustiva de la chaîne opératoire lítica de la colección gravetiense del nivel 4 de Cueva Morín.

\begin{abstract}
LABURPENA
Kantabriako eskualdeko eta, zehazki, Kantabria probintziako teknokonplexu gravetiarra, denbora askoan, Goi Paleolitikoan gutxi ikertutako eremua izan den arren, gai horren inguruan egin berria den ikerketak kokaleku mota ugari, lehengai litikoak eskuratzeko patroi ugari eta Frantziako Pirinioetako mendiekiko konexio zabalak aurkitu ditu. Zoritxarrez, ikerketa teknologiko litikoak oraindik ez dira oso ohikoak. Horrez gain, erradiokarbonoaren edo karbono-14aren datuen multzoa txikia eta adierazgarria izateak zaildu egiten du behatutako aldakortasunaren ulermen diakroniko eta erregional sakonagoa egiteko aukera. Horrenbestez, ikerketa honek datu berriak eskaini ditu Morin kobazuloko 4. mailako bilduma gravettiarraren chaîne opératoire litikoaren deskribapen zehatzerako eta adin-eredurako.
\end{abstract}

\section{ABSTRACT}

Although the Gravettian technocomplex in the Cantabrian region and the province of Cantabria in particular has long been an understudied area of Upper Palaeolithic research, recent investigation on this topic discovered a large variety of settlement types, comprehensive procurement patterns for lithic raw materials and extensive connections to the French Pyrenees. Unfortunately, lithic technological studies are still rare, which hampers, together with a small and unrepresentative radiocarbon dataset, a deeper diachronic and regional understanding of the observed variability. Therefore, this study contributes new data for the age model and a comprehensive description of the lithic chaîne opératoire from the Gravettian assemblage of Level 4 of Cueva Morín.

\section{1.- INTRODUCTION}

The Cantabrian region and the province of Cantabria in particular have a long research history for the MidUpper Palaeolithic period, dating back to around the 1910 s with the works of $\mathrm{H}$. Obermaier, J. Carballo and the Count de la Vega del Sella (OBERMAIER 1916; VEGA DEL SELLA 1921; CARBALLO 1923). Thus, one of the earliest documented Gravettian occupations in Cantabria is the level 'Auriñaciense superior', described by Vega del Sella in Cueva Morín (VEGA DEL SELLA 1921), the cave which is also the focus of this paper. Although the Gravettian has long been an understudied area of Upper Palaeolithic research (DE LA PEÑA 2009; ARRIZABALAGA 2009), recent investigations on this time period have re- vealed a large variety of settlement types (ARRIZABALAGA et al. 2015; BRADTMÖLLER 2014), comprehensive patterns for lithic raw material procurement (TARRIÑO AND ELORRIETA 2013) or extensive supraregional connections to the Pyrenees (FOUCHER et al. 2008). The actual dataset contains $\sim 30$ sites with one or more occupations covering the timeframe between 34 and 24 ky cal BP (BRADTMÖLLER et al. 2015a). Unfortunately, this dataset is still biased due to (1) the high number of investigated cave sites and low number of known open-air sites; (2) unequally distributed ${ }^{14} \mathrm{C}$ dates; and (3) a perpetually small number of lithic technological studies. Regarding the last two points, this study contributes new

(1) Research Team on Prehistory (IT-622-13). University of the Basque Country (UPV/EHU). Faculty of Letters

marcel.bradtmoeller@ehu.es 


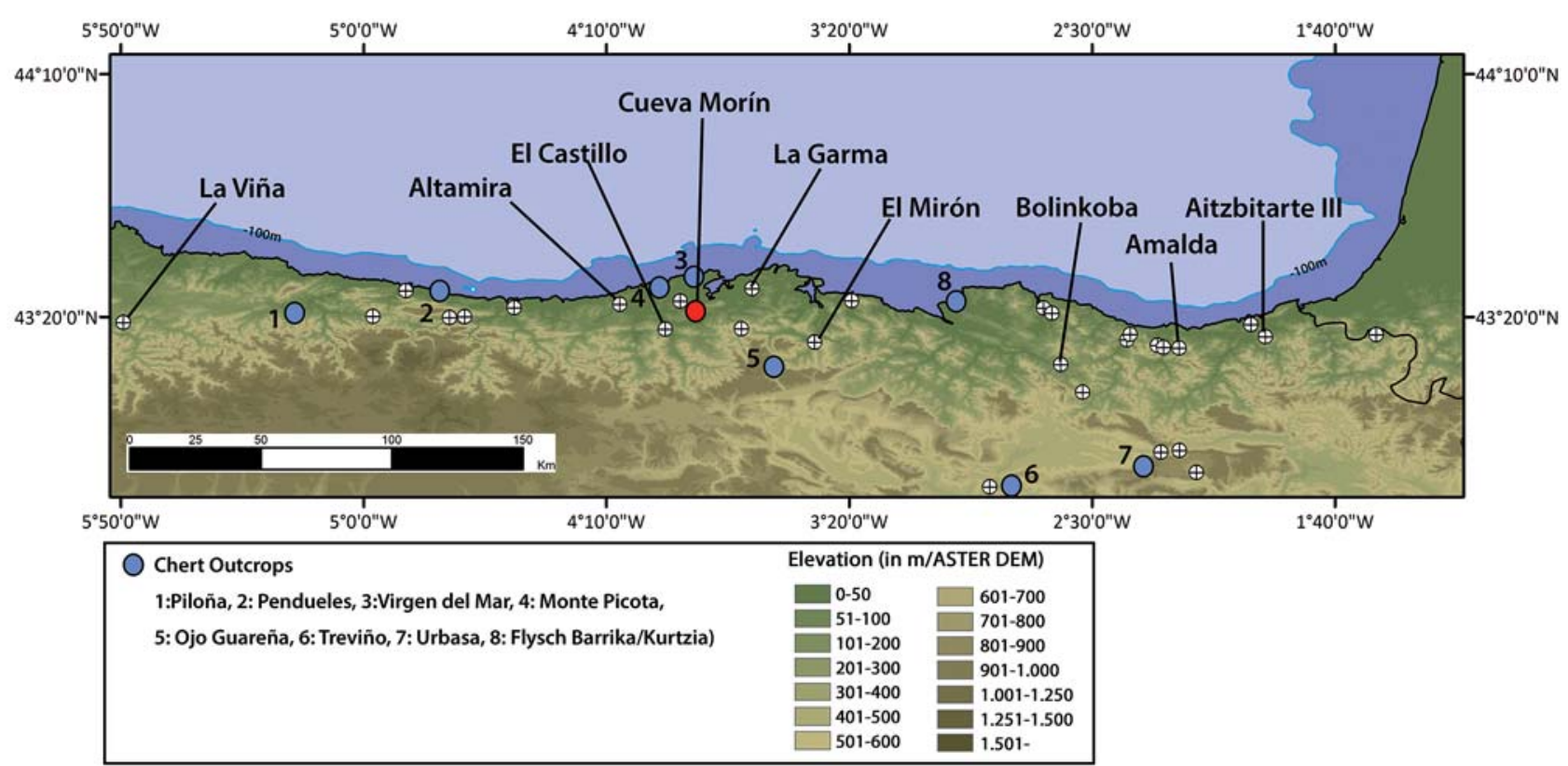

Fig. 1. Map of the mentioned Flint outcrops (after Tarriño et al. 2015) and Gravettian sites-white points (after Bradtmöller et al. in 2015A); sites mentioned in the text are labeled. Background: ASTER DEM (ASTER GDEM is a product of METI and NASA).

data for an age model of Level 4 and a comprehensive description of the lithic chaîne opératoire at Cueva Morín. Additionally, the lithic data can be evaluated in conjunction with information from the other artefact classes of Level 4 to better understand site function and human mobility.

\subsection{The archaeological site of Cueva Morín}

Cueva Morín, also known as Cueva de Villanueva and Cueva del Rey, is located $6 \mathrm{~km}$ south of the Bay of Santander in Villanueva de Villaescusa, Spain (Fig. 1). Obermaier and Wernert initially published the cave in 1910 and then subjected the site to many years of excavation (Carballo and Sierra 1912; Carballo 1917-1918; Vega del Sella 1919-1920). During these excavations, a large area within the cave was investigated, revealing a stratigraphic sequence of several metres of deposits. Nevertheless, the foundation of what is known about the site today is based on the results of a Spanish-American project led by González Echegaray and Freeman in the 1960s (ECHEGARAY AND FREEMAN 1978). In three campaigns, they uncovered " " $31 \mathrm{~m}^{2}$ with a complex stratigraphic sequence of 22 levels, spanning the Mousterian to the Azilian period. Thousands of artefacts representing several types have been studied continuously over time (e.g. BERNALDO DE QUIRÓS 1982; ARRIZABALAGA 1995; MAÍLLO-FERNÁNDEZ 2002, 2005, 2006; YRAVEDRA AND GÓMEZ CASTANEDO 2011). The Gravettian Levels
4 and 5 a were also discovered during these excavations and Level 4, more numerous in artefacts, is the focus of the investigation summarised in this paper. Nonetheless, two further campaigns by different teams followed in 2005 (MAílLLO-FERNANDEZ et al. 2014) and 2008 (URQUIJO et al. 2009), but publications of their results are pending.

\subsection{Preservation conditions and the Age Model of Level 4}

To crosscheck the age model, the faunal assemblage of Level 4 was examined in 2014 to identify bones suitable for radiocarbon dating. Because the preservation of collagen was unknown, the weight of the bone sample was set to $\geq 7 \mathrm{~g}$. Furthermore, to exclude carnivore activity and provide a direct relationship with human action, only bones with anthropogenic cut- or percussion marks were selected. Due to the limits of the project funding, finally two red deer bones were chosen. One first phalanx and one distal epiphysis of a humerus, which both samples exhibit several parallel cut marks (Fig. 3A, B). While most original spatial information for the lithic assemblage is lost, the context of many faunal remains can still be reconstructed. Therefore, we know that the sampled bones derive from square meters $X A$ and $X I A$ in the inner part of the cave (Fig.2). Samples were sent to the Poznan AMS laboratory and dated to 23,640 $190 \mathrm{BP}(\mathrm{Poz}-66758)^{1}$ and $23,790 \pm 190 \mathrm{BP}(\mathrm{Poz}-66759)^{2}$ using the ultrafiltration protocol (Fig. 4). The high amount of collagen, the low stan-

\footnotetext{
$11.0 \% \mathrm{~N}, 3.2 \% \mathrm{C}, 0.9 \%$ coll; $12.2 \% \mathrm{C}, 36.9 \% \mathrm{C}$

$21.2 \% \mathrm{~N}, 4.8 \% \mathrm{C}, 0.4 \%$ coll; $12.8 \% \mathrm{~N}, 38.0 \% \mathrm{C}$
} 


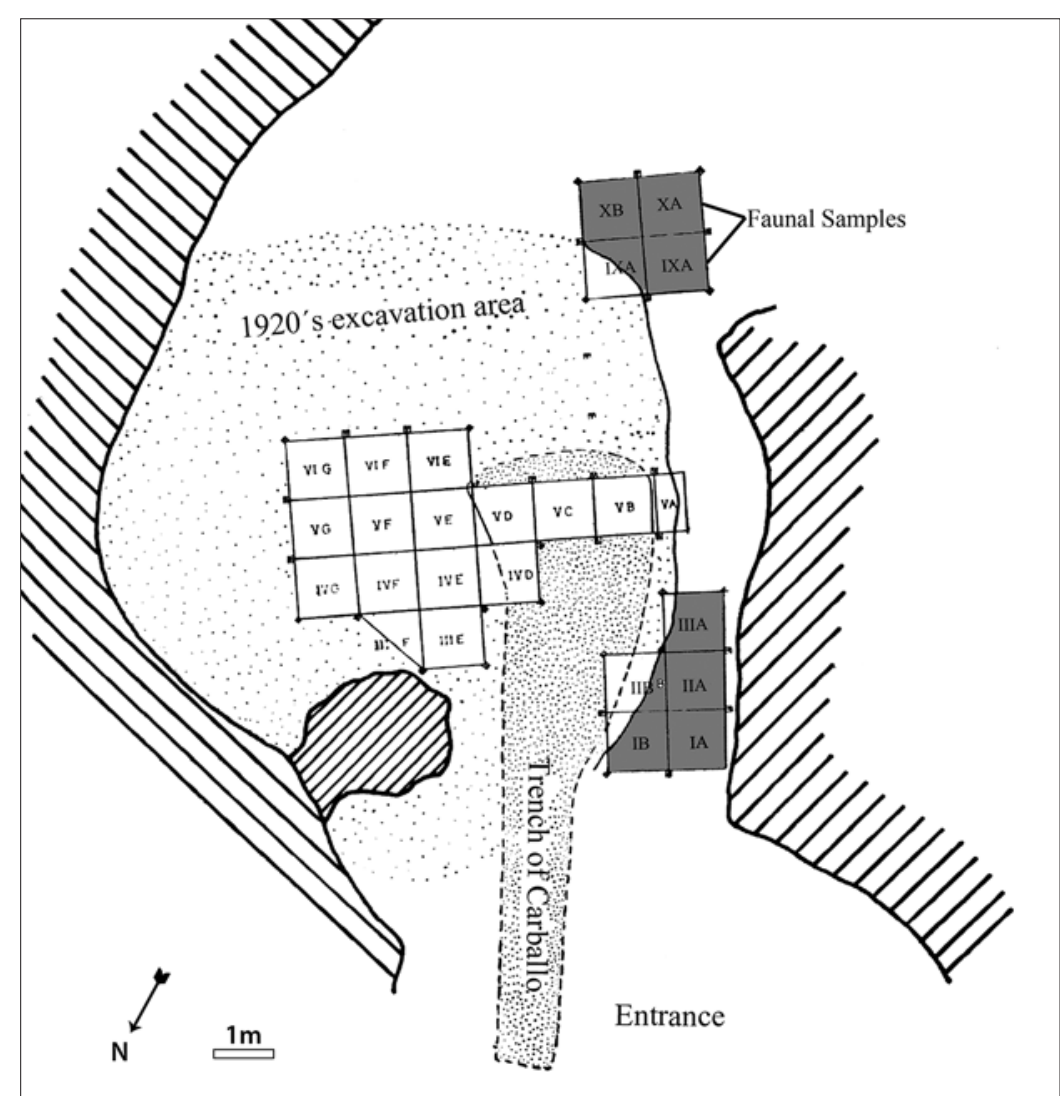

Fig. 2. Cueva Morín, Cave Plan. The grey shaded squares are showing the area of preservation for Level 4 within the excavation of Echegaray and Freeman. Modified after Maíllo et al. 2014.
Fig. 3. Faunal samples with anthropogenic cut marks for the $\mathrm{C} 14$ dating. $\mathrm{A}=$ Cervus Elaphus, first phalanx, $\mathrm{B}=$ Cervus elaphus, distal epiphysis of the humerus. 2 squares $=1 \mathrm{~cm}$.
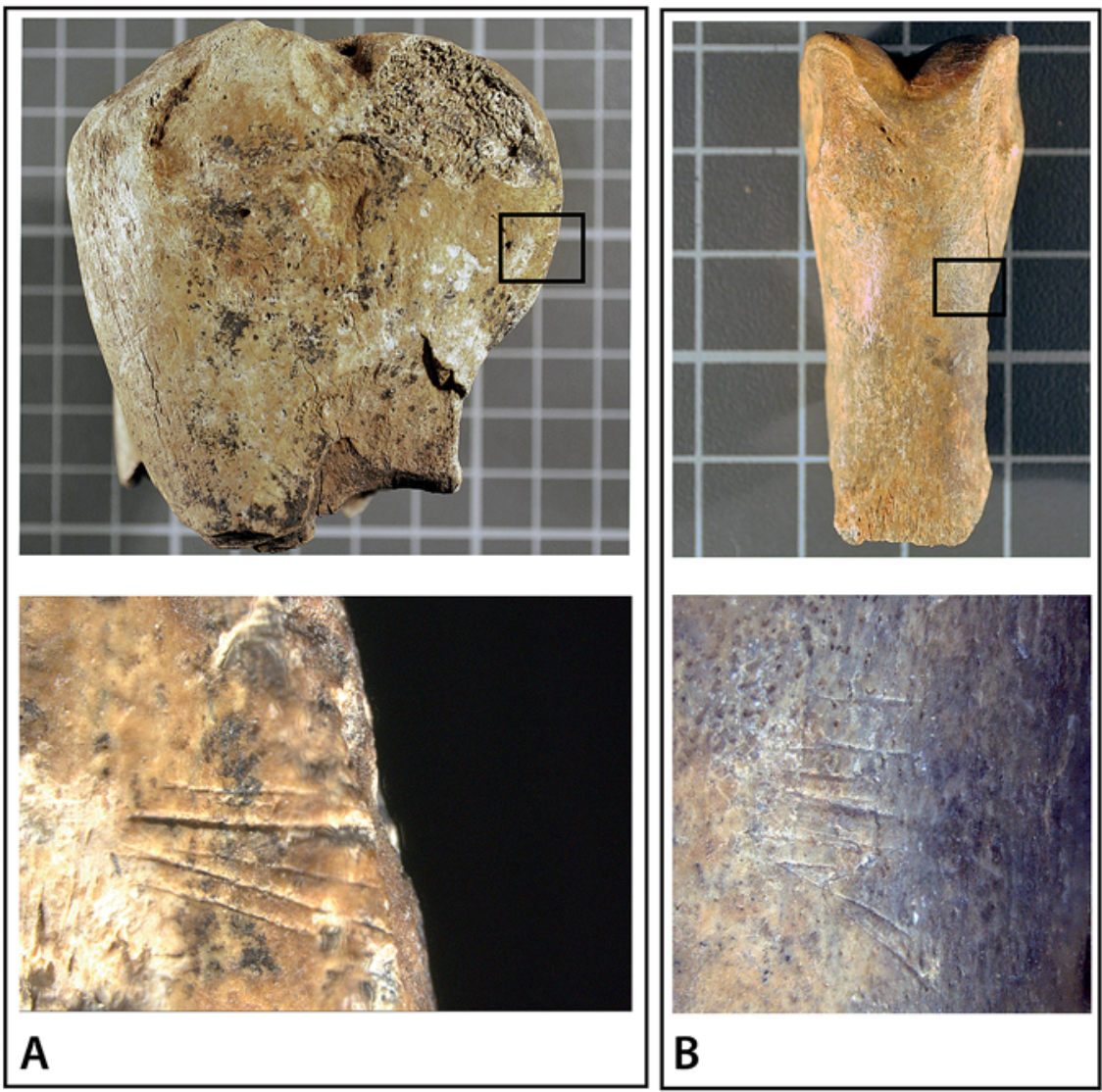


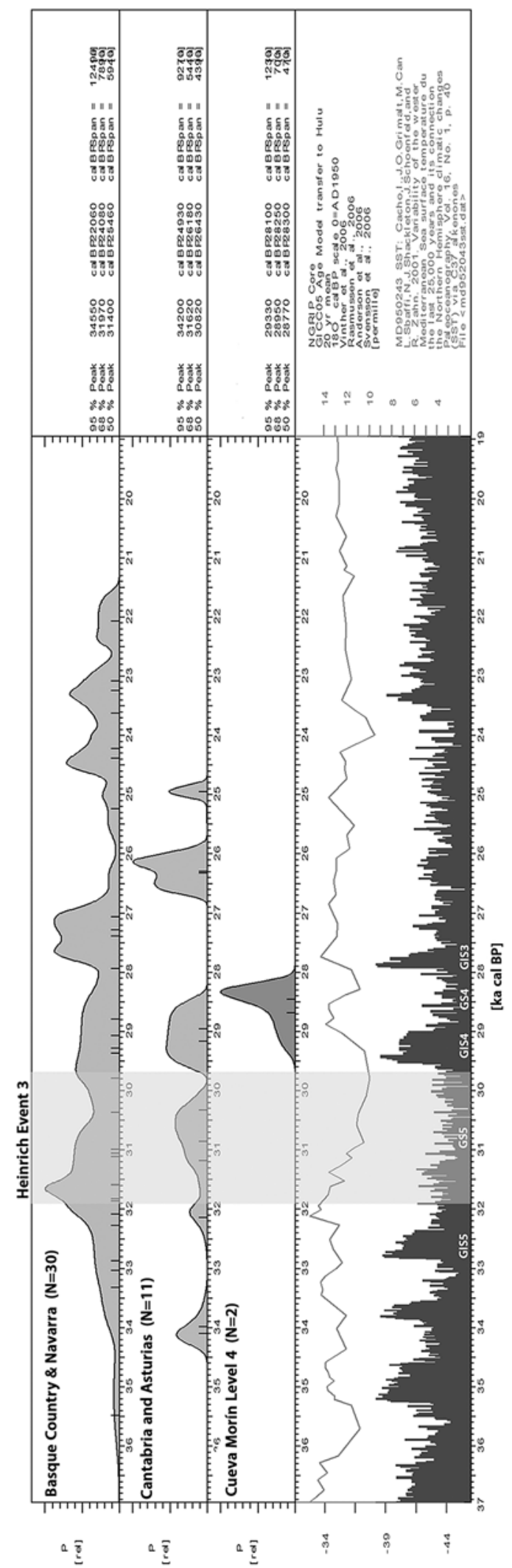

dard deviation and the statistically very similar ages thereby validate the results. Thus, the occupation falls in the younger phase of the Gravettian, after.

\subsection{Site vicinity, environmental conditions and subsistence patterns}

Within the $20 \mathrm{~km}$ radius of a potential day trip/micro move (WENIGER 1991), the catchment area of the site comprises a mosaic landscape of coastal plain and hill country. A mountainous region is present with the Peña Carbaga to the east, an area where also low quality Flint nodules are available. Today, the distance to the coast is nearly $13 \mathrm{~km}$ as the crow flies; during the Pleistocene, with a sea level of $-80 /-100 \mathrm{~m}$, it was likely ca. $20 \mathrm{~km}$ (Fig. 1). This seems to have significantly influenced human subsistence, as the composition of hunted animals reflects these local habitats. The faunal assemblage contains a minimum of 11 individual red deer (Cervus elaphus), the dominant prey. This is followed by four roe deer (Capreolus capreolus), three ibex (Capra pyrenaica), three bovines (two each Bos sp., one Bos primigenius), one chamois (Rupicapra rupicapra), two horse (Equus caballus) and one bison (Bison priscus) (ALTUNA 1972; YRAVEDRA AND GÓMEZ CASTANEDO 2011; YRAVEDRA 2002, 2013). Many larger bones show cut- and percussion marks, but carnivore activity is also evident. Due to the high fragmentation of bones, providing a general model for the prey transport processes is not possible. What can be discerned is the transport of complete deer, roe deer and horse carcasses and the selected transport of the bovines focused on appendicular limbs (J. Yravedra, personal communication).

Reconstructing the local palaeoenvironmental conditions is complicated. A palynological analysis was conducted by Leroi-Gourhan (1971), but her results show strong alterations of different climatic conditions even within levels and are thus not relevant to this discussion. A sedimentary analysis has shown results possibly indicating temperate conditions for Level 4 (BUTZER 1981). While the lack of cold-adapted reindeer in the assemblage supports this hypothesis, the recent identification of steppe bison suggests rather cold climate conditions. This fits well with the general reconstruction of a relatively open and dry landscape during the Gravettian with a high amount of Artemisia and the small but regular appearance of juniper, pine, birch and hazel (IRIARTE AND MURÉLAGA 2013; DE LA PEÑA 2013). Furthermore, the calibrated age of new radiocarbon dates places the occupation in the timeframe of Greenland Stadial 4. However, the steppe bison is only represented by one bone. In addition, with a broader landscape shaped by environmental refugia, both interpretations could be of significance.

Fig. 4. The radiocarbon chronology for the Cantabrian region, divided into Basque Country/Navarra, Cantabria/Asturias and the two new conducted C14 dates from Level 4. Only AMS data. Dataset: Bradtmöller et al. 2015A. Calibrated with CalPal2007Hulu (Weninger et al. 2008). Spatial scale for the Heinrich Event 3: López-García, et al. 2014). 


\section{2.- METHODS AND MATERIALS}

The Level 4 lithic assemblage was studied within the wider framework of a doctoral thesis investigating the technological and typological variability of the Gravettian from the Cantabrian region (Bradtmöller 2014). The goal of the conducted attribute analysis (DRAFEHN et al. 2008) was to gain a comprehensive overview of lithic exploitation strategies and their further modification and utilisation as tools. The technological interpretation is mainly based on Inizan et al. (1992), but several other publications were also referenced (e.g. BAUCHE 1987; SCHÖN 1996; HARTZ 1999). The typological classification was conducted based on several publications of different tool classes (HAHN 1978; ARRIZABALAGA 1994; KLARIC 2007; MOREAU 2009; SIMONET 2009). The restricted number of microscopic classifications of raw material units were done with a Dino-Lite Digital Microscope (20X$60 X)$. The total number of studied lithic artefacts is 3802 , dominated by flakes $>1 \mathrm{~cm}(53.7 \%)$, followed by debris $<1 \mathrm{~cm}(23 \%)$ and laminar blanks (7.5\%). The percentage of modified pieces is 5.5\%, quite similar to modern excavations of Gravettian occupations (e.g. CAVA et al. 2009), with a strong focus on laminar blanks (Table 1).

\section{3.- TECHNOLOGICAL ORGANISATION}

\subsection{Taphonomic processes}

Artefact preservation, dimension and remaining cortex are important attributes for investigating on-site lithic reduction strategies as well as evaluating potential taphonomic processes (cf. HISCOCK 2002). In total, the preservation status of artefacts can be classified as good, with a low degree of rounded edges, but a high rate of surface patination. Most edge damage shows fresh, unpatinated fractures, most likely caused by the storage procedure that sometimes involves placing several hundred artefacts (mostly unmodified, small flakes) inside of one bag. Of further interest is the high degree of completely preserved unmodified blanks $>1 \mathrm{~cm}(50.8 \%)$. This percentage seems to be influenced by the well-preserved abundant flake assemblage (54.0\% complete), while in contrast blades and bladelets are more often fragmented. This situation can be explained by a combination of postsedimentary disturbance like trampling (BUTZER 1981) and blank selection by humans.

Some artefacts were partly coated with a red substance that could be interpreted as hematite residue (Fig. 5: 24), a mineral that was also documented as a raw material within Level 4. Several more pieces exhibit concentrated black spots on the surface (Fig. 5: 4). Recently conducted usewear and multispectral analyses, for the moment in preparation for publication, verified that these are traces of an ancient adhesive, most likely used for hafting.

Attributes pointing to an external thermal influence, like colour change, craze or cracks are documented on $18.8 \%$ artefacts of the assemblage, with many objects showing signs of intensive fire damage (in 81 cases the blank type was impossible to classify because of thermal fracturing). Though intensive natural fires within cave sites are unlikely, anthropogenic fires will potentially produce extensive thermal damage to archaeological remains. Moreover, while no intentional selection of artefacts for thermal treatment could be verified, the documented damage most likely occurred unintentionally within fireplaces.

\begin{tabular}{|c|c|c|c|c|c|c|c|}
\hline & Total & $\begin{array}{c}\text { indeterminate } \\
\text { Flint }\end{array}$ & Flysch & Treviño & Quartzite & Quartz & Diverse \\
\hline Debris $(<1 \mathrm{~cm})$ & 710 & 665 & 5 & 2 & 28 & 5 & 5 \\
\hline Flake $(>1 \mathrm{~cm})$ & 1750 & 1256 & 198 & 99 & 135 & 42 & 20 \\
\hline Blade & 144 & 62 & 46 & 24 & 9 & 1 & 2 \\
\hline Bladelet & 30 & 13 & 9 & 8 & 0 & 0 & 0 \\
\hline Burin spall & 69 & 43 & 13 & 7 & 6 & 0 & 0 \\
\hline Core & 19 & 7 & 4 & 5 & 2 & 1 & 0 \\
\hline Exhausted Core & 10 & 7 & 2 & 1 & 0 & 0 & 0 \\
\hline Core Tablet & 2 & 1 & 1 & 0 & 0 & 0 & 0 \\
\hline Partial Core Tablet & 33 & 18 & 10 & 4 & 0 & 1 & 0 \\
\hline Crested Blade & 1 & 0 & 0 & 1 & 0 & 0 & 0 \\
\hline Crested Flake & 2 & 1 & 0 & 1 & 0 & 0 & 0 \\
\hline Rejuvenation Blade & 23 & 12 & 6 & 4 & 1 & 0 & 0 \\
\hline Rejuvenation Flake & 13 & 7 & 3 & 2 & 0 & 0 & 1 \\
\hline Languette Fragment & 3 & 1 & 0 & 2 & 0 & 0 & 0 \\
\hline Plunging Flake & 29 & 15 & 6 & 6 & 2 & 0 & 0 \\
\hline Siret Fracture & 8 & 4 & 1 & 2 & 1 & 0 & 0 \\
\hline Thermic Waste & 81 & 66 & 6 & 2 & 5 & 1 & 1 \\
\hline Artificial Waste & 141 & 109 & 13 & 9 & 8 & 1 & 1 \\
\hline Information not available & 734 & 727 & 0 & 0 & 0 & 4 & 3 \\
\hline Total & 3802 & 3014 & 323 & 179 & 197 & 56 & 33 \\
\hline
\end{tabular}

Tabla 1: Artefact types separated after the main raw material units. The row "Information not available" contains artefacts, which were analysed with a shortened attribute analysis (mainly unmodified blanks and debris). 

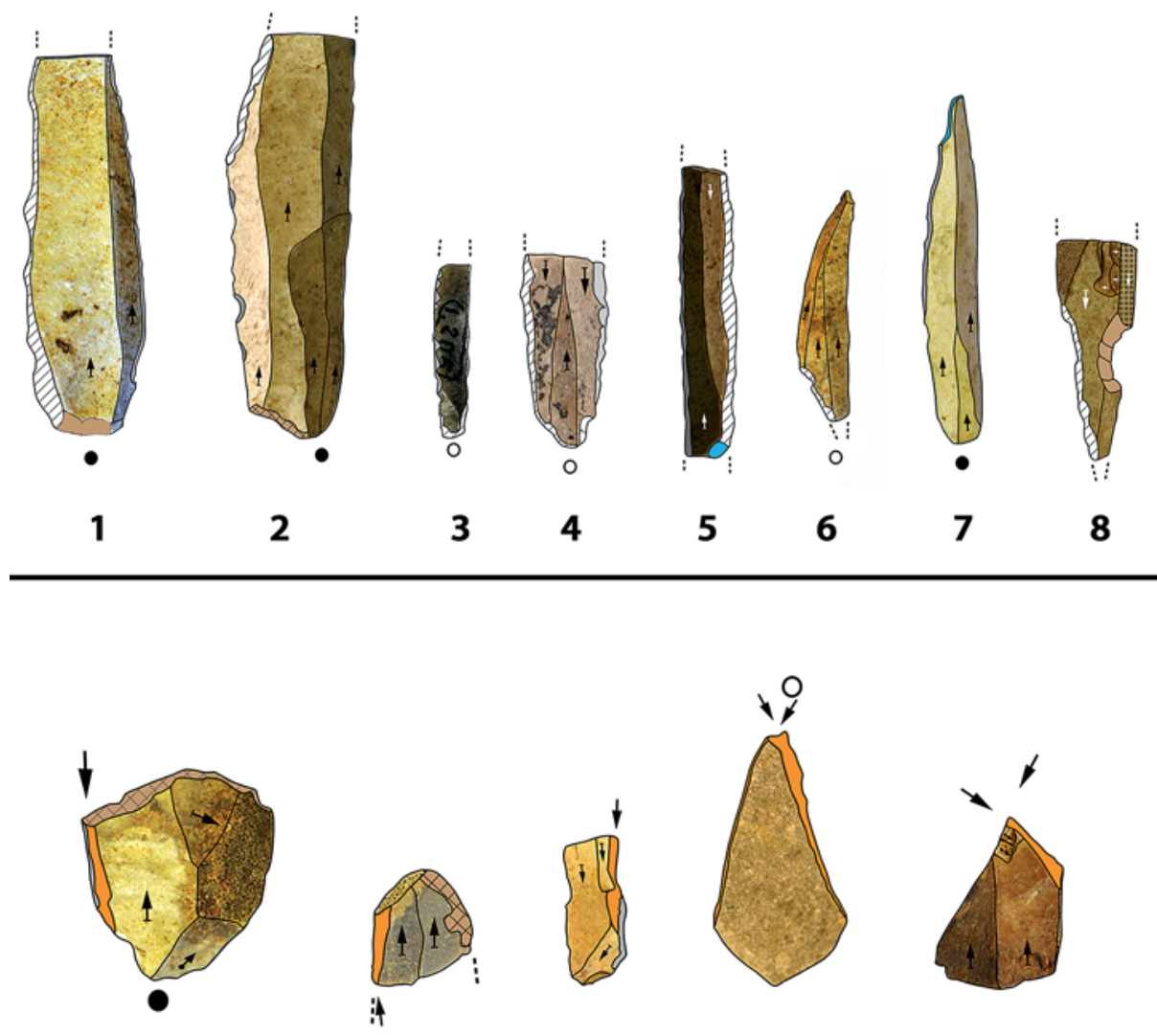

11

12

\begin{abstract}
13
\end{abstract}
14

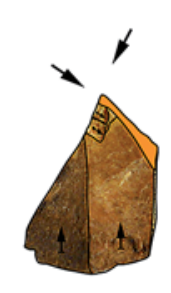

15

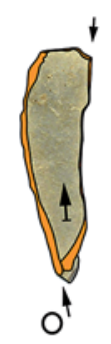

16
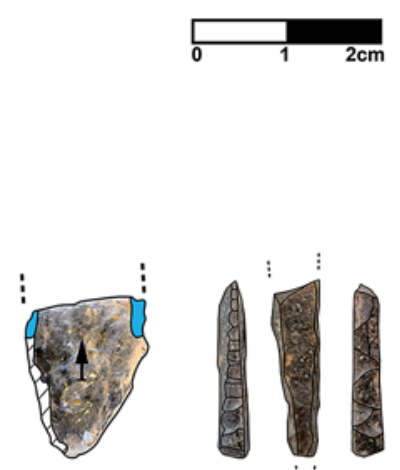

9

10
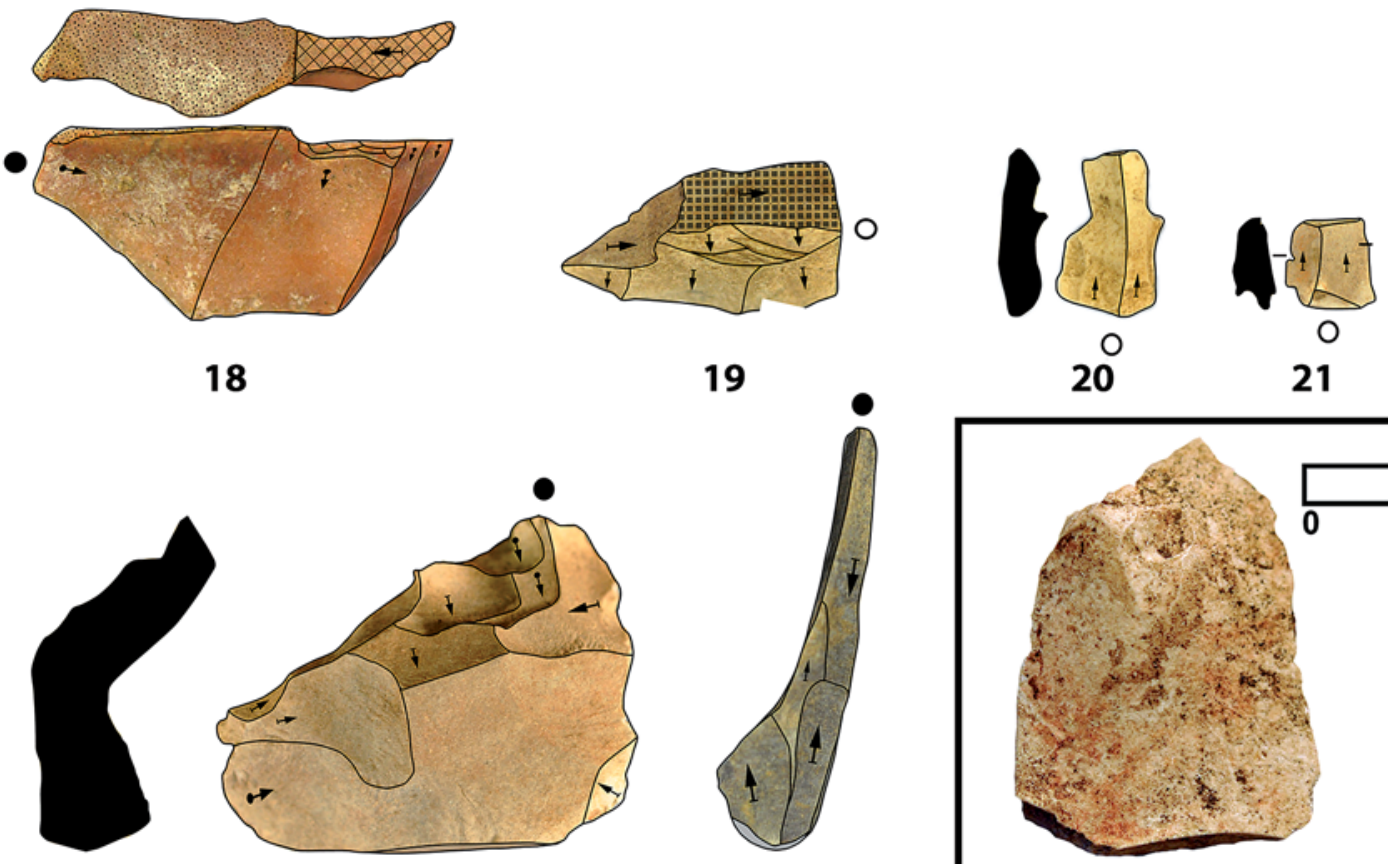

18

19 20

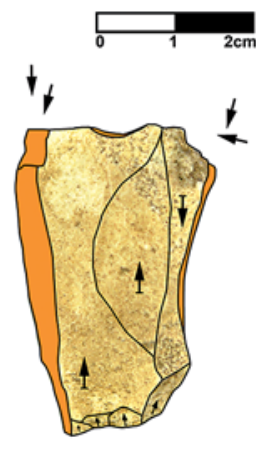

17

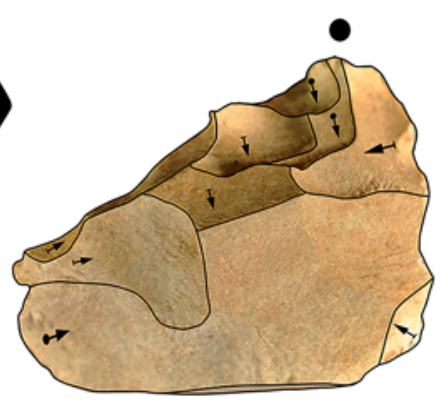

22
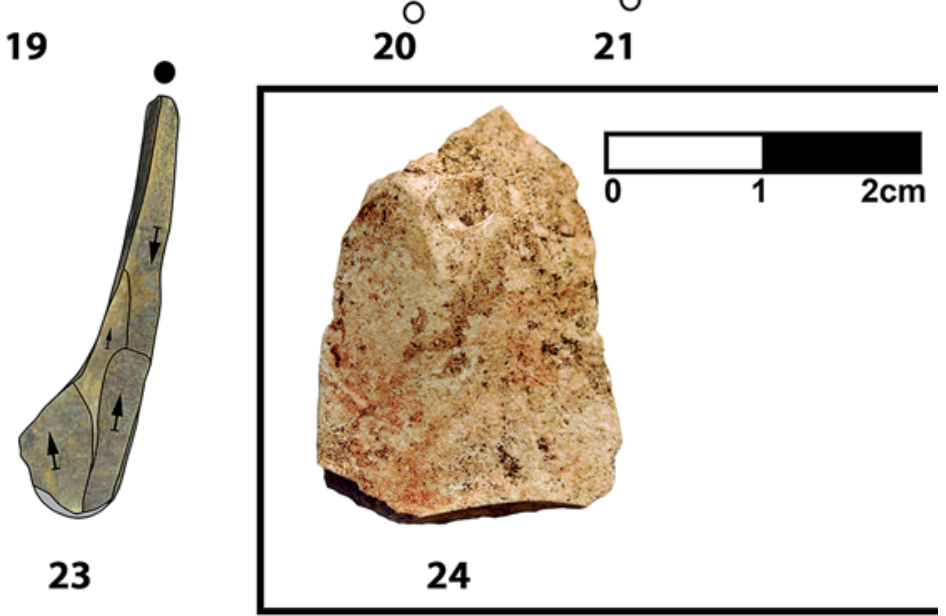

Fig. 5. Lithic artefact from Level 4: 1- 10 Backed pieces, 10 - 17 Burins, 18 Rejuvenation Flake, 19 Partial Core Tablet, 20 - 21 Languette Fragments, 22 - 23 Plunging flakes, 24 Artefact with ochre residue. Signatures - white: backed, grey: simple retouch, orange: burin negative, blue: impact fractures. 
When studying the relationship between size classes (hereafter, SC; after ARNOLD 1987, in HARTZ 1999) and remaining cortex of the artefacts, two aspects become visible. First is the low number of debris (SC VIII, $n=746$ ), which is unusual for an occupation with intensive lithic reduction at a site excavated using modern techniques. However, as Butzer (1981: 156) stated, '[... ] lithic artifacts contribute significantly to the sand and grit component, as does fine chipping debris. This material, amounting to as much as $100 \%$ of some sieve fractions, was microscopically identified according to lithology and shape, and removed and excluded from the totals'. Thus, we need to consider that documentation and curation methods are the primary factors behind their low number. To better understand the original assemblage size, note that the 2008 excavation of a mere $0.5 \mathrm{~m}^{2}$ recovered over 2000 artefacts $>4 \mathrm{~mm}$ from Level $5 \mathrm{a}$ (cf. URQUIJO et al. 2009; BRADTMÖLLER 2014). Considering the studied area of $6.5 \mathrm{~m}^{2}$ and the total number of artefacts $>1$ $\mathrm{cm}$, the original quantitiy of debris from Level 4 was reconstructed to 6350 , totalling more than 10,000 artefacts overall (if the numerical proportion of the bigger size classes is similar between the two levels).

Nonetheless, the high quantity of small $(>1 \mathrm{~cm})$ and medium-sized artefacts suggests the local origin of some comprehensive reduction sequences or complementary parts of them (Fig. 6, left). This is supported by the amount of cortex, which stands in relation to the artefact size (Fig. 6, right; after HÖHN 1997). Thereby the majority shows only a small amount of cortex, with $80.8 \%$ completely lacking natural surface and only $0.8 \%$ completely covered. This suggests an off-site testing and initialisation of the raw material and the import of roughly trimmed cores to the site (or the excavated area of the site).

\subsection{Raw material availability and assemblage composition}

As reported in a recent publication (CALVO et al. 2015), the local availability of high-quality knapping material (especially flint) is of high relevance for understanding the visible patterns of lithic reduction in Northern spain. In total, 92.5\% of artefacts were made of flint, a raw material that can be ga-

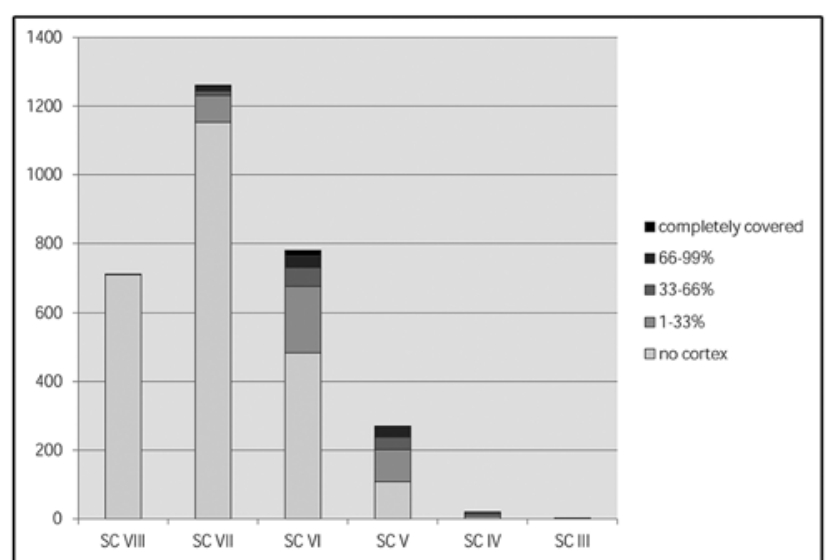

Fig. 6. Relationship between Cortex cover and Size Class (SC) of all artefacts. thered throughout the whole province. Nonetheless, the distribution of outcrops with high/medium quality knapping material shows a clear coastal tendency, while in the hinterland these quality is only available in the Ojo Guareña region (RISSETTO 2009; TARRIÑO et al. 2015). Cantabria reflects thereby a different setting than e.g. the Basque Country, where high-quality flint farther inland was more scattered available. Therefore, secondarily deposited material from local riverbeds could be quite important not only for the procurement of quartz, quartzite, but also flint (SARABIA 1999). The latter is supported by the high artefact quantity showing a pebblelike cortex (23.1\% for the indeterminate flint).

Due to the artefacts' small dimensions, the intensity of thermal surface alterations and strong patination, it was only possible to classify the exact flint unit macroscopically for $20.4 \%$ of the assemblage. Most indeterminate artefacts were likely made on Lower Cretaceous flint from Peña Carbarga that can be regularly found in primary and secondary deposition around Santander. Furthermore, several pieces could be attributed to the autochthonous Palaeocene carbonate marine platforms flint of Monte Picota (Fig. 7: 1; TARRIÑO et al. 2009, 2015). This assumption is supported by a generally small mean blank dimension, suggesting a small raw nodule size (RISSETTO 2009), as well as the low quality of this material (Fig. 7: 5). This pattern corresponds well to the earlier study of Sarabia (1999), who assigned a value of $72.6 \%$ for the local flint among artefacts in Level 4. However, while Sarabia intensively studied the allocation of local flint varieties, this study focuses on the distribution of allochthonous varieties to better understand the regional component of human mobility.

In doing so, two flint varieties of exogenous character (>20 km radius) could be clearly assigned. These include 323 artefacts made of Flysch (8.5\%) and 179 pieces of Treviño $(4.7 \%$ ) (Fig. $7: 2,3)$. While the majority of these pieces was classified macroscopically, some artefacts could be confirmed by their microscopic characteristics (TARRIÑO 2006; TARRIÑO et al. 2015). At least for the artefacts made from Treviño flint, this indicates a transport distance of over $100 \mathrm{~km}$ as the crow flies to outcrops in the Basque hinterland (Fig. 1). The potential source of the Flysch flint is more

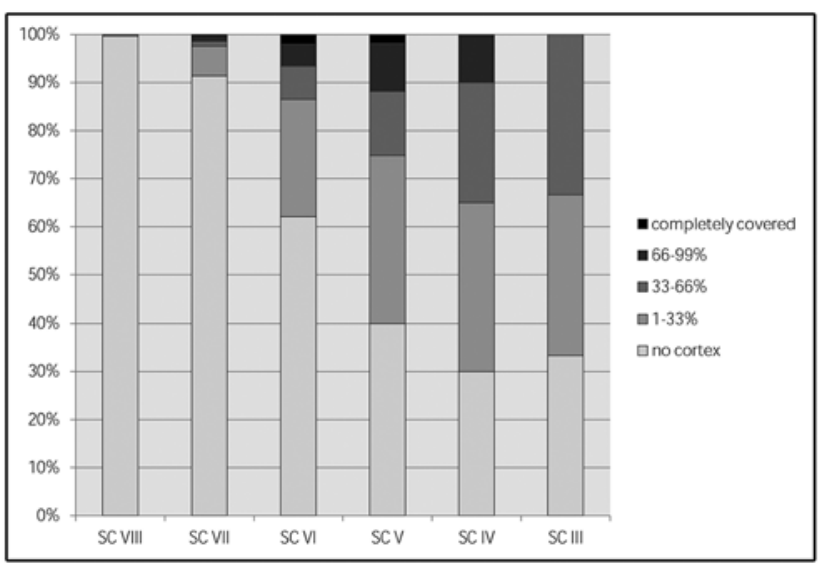


challenging to identify, as only four banded artefacts can be attributed to the banded variety of Flysch type Kurtzia deriving from the estuary of Bilbao. As presently known, this point marks the westernmost distribution of most flint-bearing Flysch formations, but flint was also recognised within the Flint formations of Pendueles in Asturias (MARTİNEZ GARCìA et al. 1971; TARRIÑO et al. 2015). Thus, it is only possible to state that the transport distance was at minimum $60 \mathrm{~km}$. Likewise, a small group of artefacts $(n=3)$ could be further assigned to the varieties of Piloña in Asturias (Fig. 7: 4) and possibly Urbasa in the Basque hinterland.

The non-flint assemblage is dominated by $5.2 \%$ quartzite (Fig. 7: 6) and 1.5\% quartz, both assigned as local raw materials. The quartzite and quartz were most likely imported from the Rio Pisueña $(\sim 6 \mathrm{~km})$ or the Obregón $(\sim 100 \mathrm{~m})$ riverbed (SARABIA 1999). Additional local raw materials are mountain crystal $(n=12)$, sandstone $(n=9)$ green ophite $(n=4)$ and red lutite $(n=3)$.

\begin{tabular}{|l|c|c|c|c|c|c|}
\hline & Total & $\begin{array}{c}\text { Indeterminate } \\
\text { Flint }\end{array}$ & Flysch & Treviño & Quartz & Quartzite \\
\hline Unidirectional Flake Core & 1 & 0 & 0 & 1 & 0 & 0 \\
\hline Multidirectional Flake Core & 9 & 4 & 1 & 1 & 1 & 2 \\
\hline Carinated Core & 1 & 0 & 0 & 1 & 0 & 0 \\
\hline Burin Core & 3 & 1 & 0 & 2 & 0 & 0 \\
\hline Splintered Piece / Bipolar Core & 2 & 1 & 1 & 0 & 0 & 0 \\
\hline Unidirectional Laminar Core & 0 & 0 & 0 & 0 & 0 & 0 \\
\hline Multidirectional Laminar Core & 1 & 0 & 1 & 0 & 0 & 0 \\
\hline Pyramidal Core & 2 & 1 & 1 & 0 & 0 & 0 \\
\hline Exhausted Core & 10 & 7 & 2 & 1 & 0 & 0 \\
\hline
\end{tabular}

Tabla 2: The documented core types and their raw material classification.

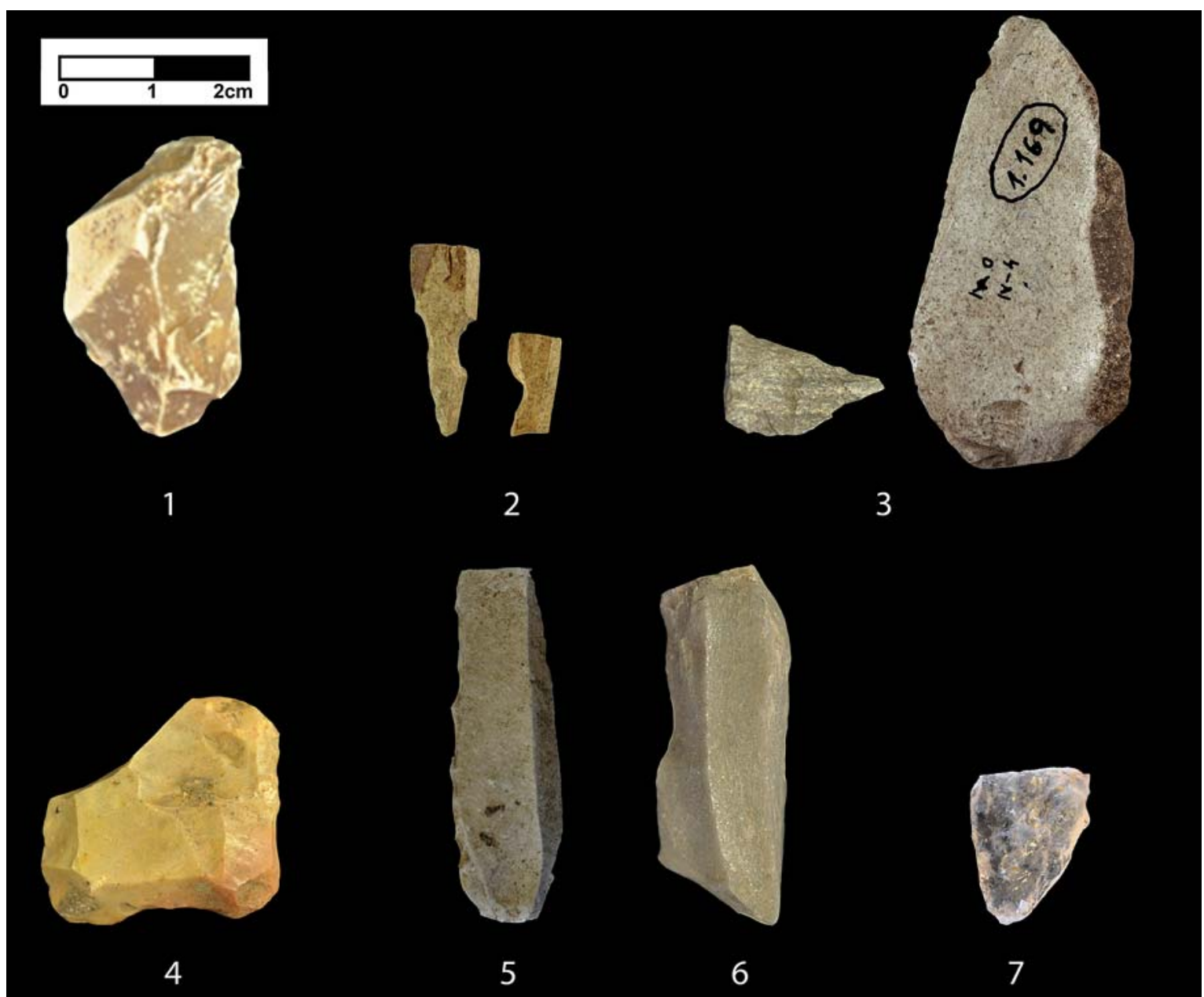

Fig. 7. Most important raw material units: 1: Monte Picota, 2: Treviño, 3: Flysch, 4: Piloña, 5: low/medium quality Flint of unknown source, 6: high quality Quartzite, 7: Mountain crystal. 


\subsection{General exploitation strategies}

With refitted artefacts lacking, the quantitative and qualitative analyses of the documented attributes for cores, characteristic debitage and blanks are the primary information sources used in this study.

\subsubsection{Core morphology}

Cores are classified by morphology and comprise two completely preserved blank negatives $(n=19)$. Pieces with core attributions, but without two completely preserved negatives are labelled as wasted cores $(n=10)$. The broad array of different reduction schemes is remarkable (Tab. 2; Figs. 8, 9). Laminar production was conducted on carinated cores (Fig. 8: 5), burin cores (Fig. 9: 4), bipolar cores/splintered pieces (Fig. 9: 2), pyramidal cores (Fig. 9: 3 ) and laminar cores of prismatic shape. Flake production was practiced with uni- and multi-directional flake cores (Fig. 8: 1, 4; Fig. 9: 1). Thus, this occupation shows the complete selection of known reduction schemes from the Gravettian technocomplex of the Cantabrian region (cf. DE LA PEÑA 2012; BRADTMÖLLER 2014; BERNALDO DE QUIRÓS et al. 2015; CALVO et al. 2015).

While carinated elements and the splintered pieces are reduced on former blanks (mainly big flakes), their weight and amount of cortex are low. Of more interest are these attributes for the other core classes. The biggest size class (III) and highest weight with an arithmetic mean (AM) of $288.2 \mathrm{~g}$ are documented for flake cores, but the preserved blade core is also relatively heavy at $263 \mathrm{~g}$ (Fig. 8). In contrast, the pyramidal laminar cores are slightly smaller $(225 \mathrm{~g}$ and $113 \mathrm{~g})$. The smallest dimension is documented for the exhausted cores with an AM of $75.8 \mathrm{~g}$, which likely represent the size limit warranting exploitation by Pleistocene hunter-gatherers.

The exhausted cores reflect the end stage of a long reduction sequence, as supported by their low cortex proportions; six examples had no cortex and two additional pieces show only minimal remains $(<33 \%)$. This is a unique result compared to the large flake cores, in which five of nine artefacts have between $33 \%$ and $66 \%$ cortex remaining. The latter can be interpreted as an early discard of these pieces and suggests the appearance of a distinct flake production process. With a nearly completely covered, unprepared back, the blade core also shows a high cortex value $(>33 \%<66 \%)$, while the pyramidal cores are positioned at the end of the sequence $(<33 \%)$. This is an expected pattern within the Gravettian technocomplex, as blade-bladelet production on prismatic/pyramidal cores is claimed to run continuously until core discard (BRADTMÖLLER 2014; CALVO et al. 2015). In both cases, flake and blade core production involves a simple preparation of the striking platform via one or two flake reductions. Concerning the general core orientation, the preserved prismatic blade core shows unipolar reduction with some bidirectional negatives, most likely for maintaining the convexity of the reduction surface (Fig. 8: 3). This pattern co- rresponds with the dorsal negatives of the blanks; $75.7 \%$ of the blades show parallel negatives, a value similar to Gravettian sites from the Basque Country like Bolinkoba (75.9\%; BRADTMÖLLER 2014) or Mugarduia sur (79.8\%; BARANDIARÁN et al. 2013).

Flake reduction shows a similarly heterogeneous picture. While only one core exhibits a unipolar reduction, three cores are showing a bi- or multidirectional exploitation (Fig. 8: 1). Furthermore, two pieces show a configuration in which one striking platform serves as the reduction surface of the other (Fig. 8: 4). Three additional examples exhibit a $90^{\circ}$ shift in striking direction when using the old reduction surface as the new striking platform (Fig. 8: 2), a configuration that can be also observed in other sites, e.g. Aitzbitarte III exterior (ext.) (DE LA PEÑA 2012). This heterogeneity is also documented among the flakes. Only $49.2 \%$ indicate a unidirectional pattern, while $18.7 \%$ exhibit transverse running negatives. The latter group could be assgined to the documented $90^{\circ}$ shift in striking direction. The rest show even more complex direction combinations (32.1\%).

A further 'core on blank' strategy is the bipolar anvil method that produces characteristic cores, traditionally called splintered pieces (Fig. 9: 2). Although a use for the blank production could not be identified for all artefacts (for the functional interpretation, see SHOTT 1999), the size, a straight edge morphology and regular blank negative support this interpretation in at least two cases (cf. DE LA PEÑA 2011). The same general classification problem is known for the burins/burin cores. These artefacts exhibit a high morphological diversity and were used during the Gravettian for bone and antler working, but also served as laminar cores (TOMÁSKOVÁ 2005). Based on size and morphology, four examples could be assigned as cores (Fig. 9: 4-7). An additional 57 artefacts are classified as burins sensu lato, but some of these likely also functioned as laminar cores, perhaps in a secondary role (Fig. 5: 11-17). The importance of burins for the laminar production is also supported by the 10 modified burin blanks. Finally, four burin spalls show traces of a regular retouch or macroscopically visible usewear traces (MT) on their lateral edges. While these predate the reduction, these pieces can be interpreted as debitage from resharpening the functional lateral edge.

\subsubsection{Characteristic debitage}

Classified as characteristic debitage, 114 artefacts providing direct information about different aspects of the reduction process. The smallest group of these constitute the crested blanks $(n=3)$. Although the initialisation of cores by means of ridge preparation is a well-known practice in the Cantabrian region (e.g. BARANDIARÁN et al. 2013; DE LA PEÑA 2012) and the broader European context (e.g. MOREAU 2009; WIERER 2013), their low number is is consistent with the generally low amount of cortex.. Both factors imply an off-site core initialisation. Moreover, two of the crested pieces are tools and may have been imported instead of locally produced. 

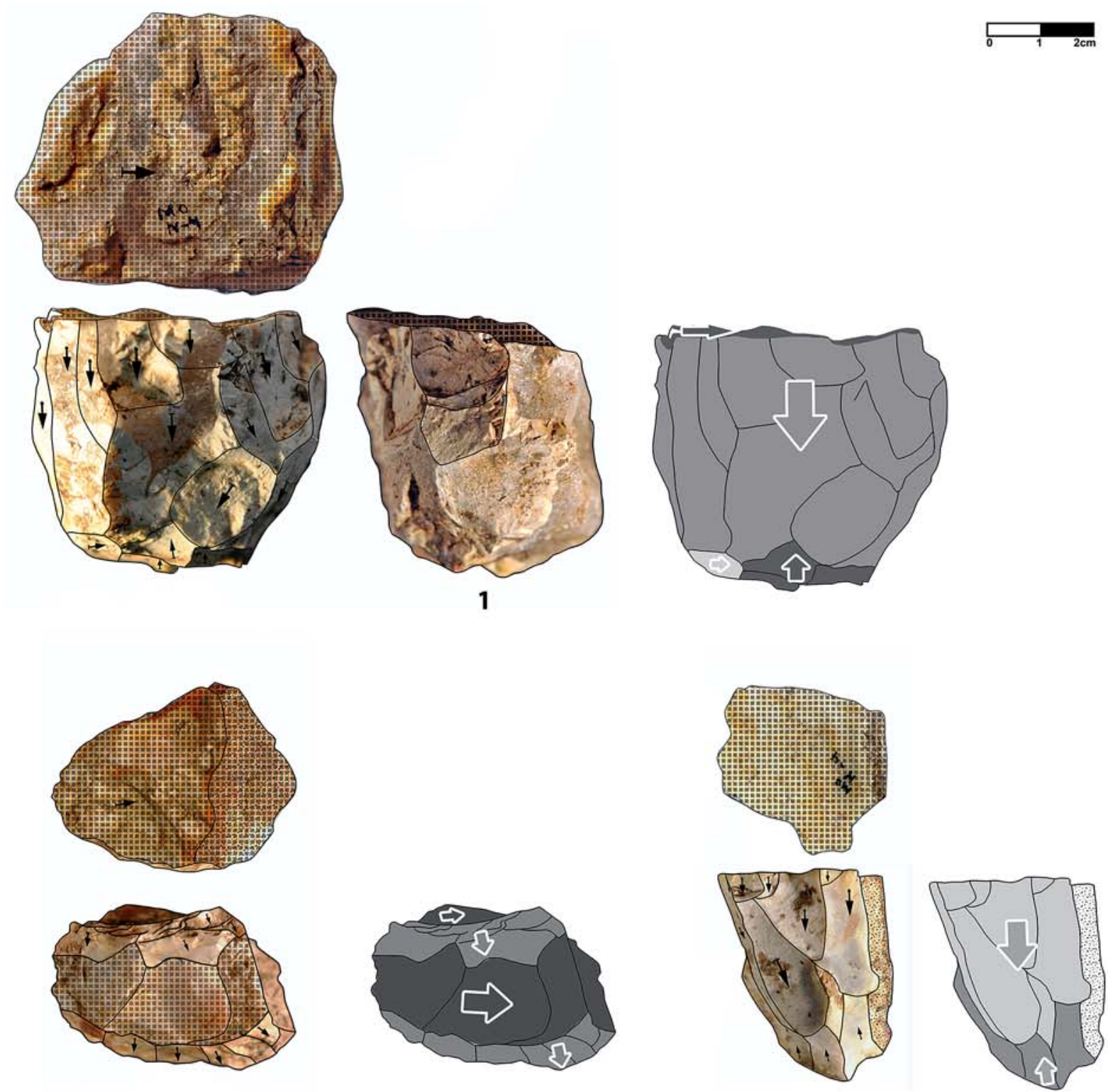

2

3
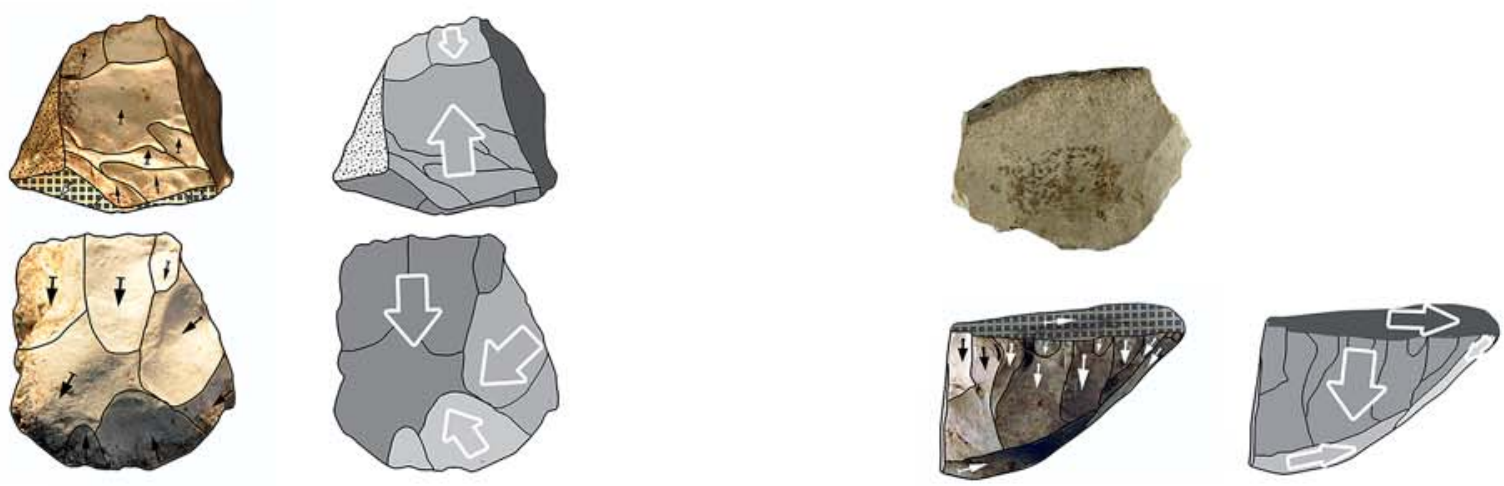

4

5

Fig. 8. 1: Polyhedral flake core, 2: Multidirectional flake core, 3: Prismatic Blade Core, 4: Multidirectional flake core, 5: Carinated Core. 

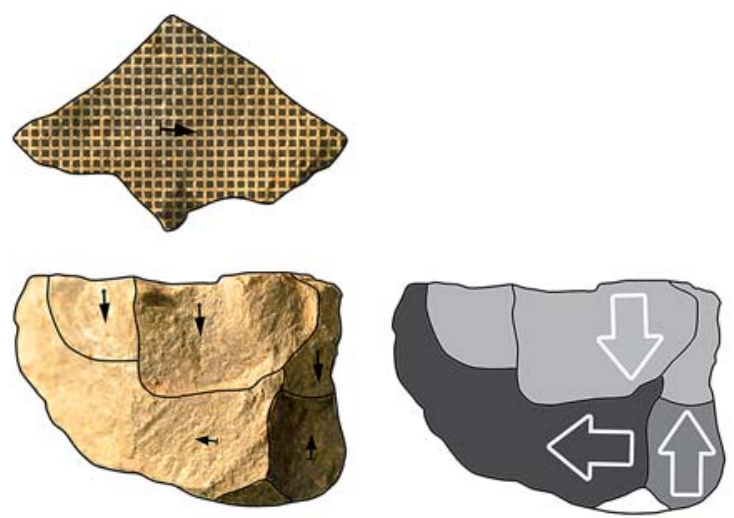

1

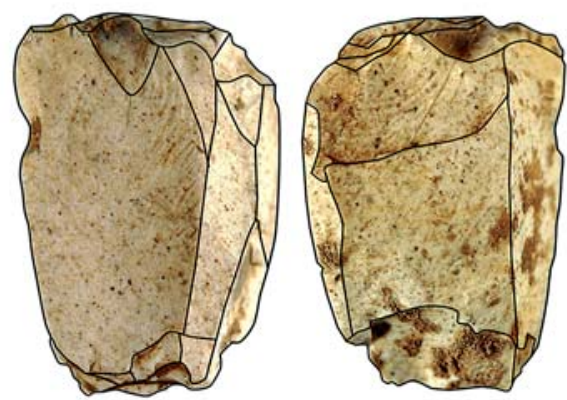

2
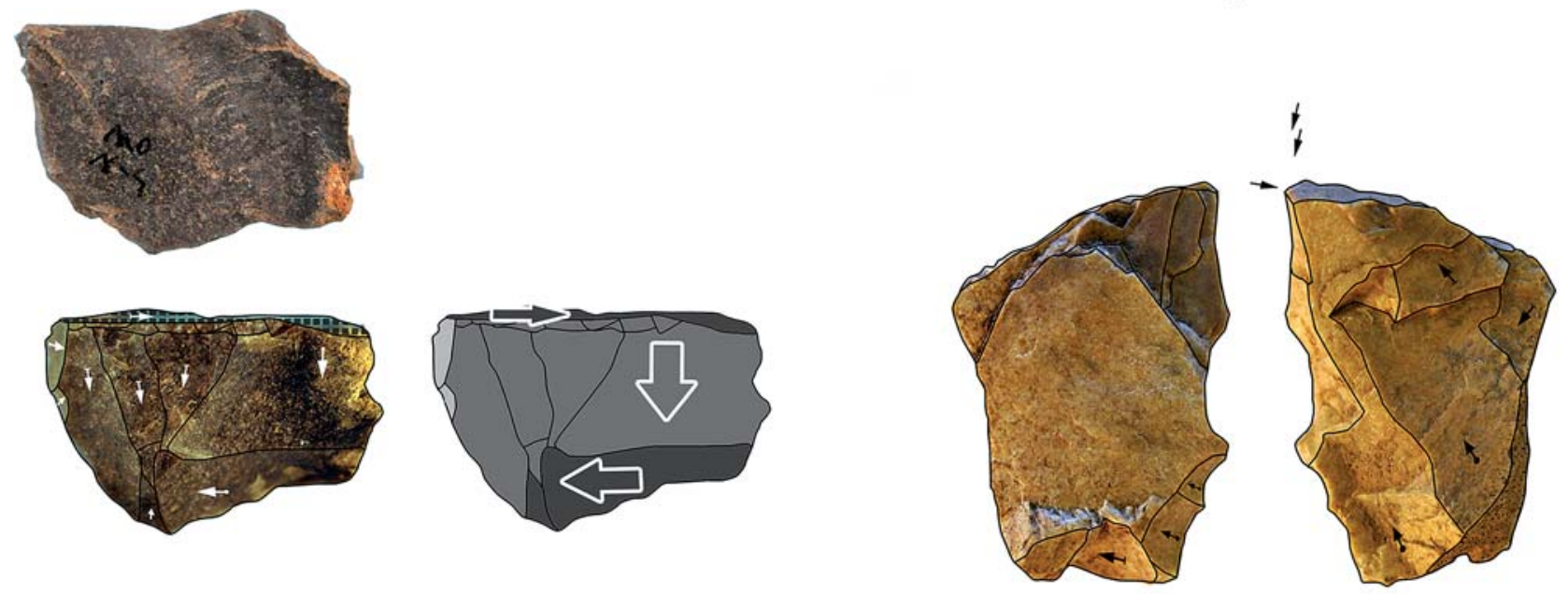

3

\section{4}

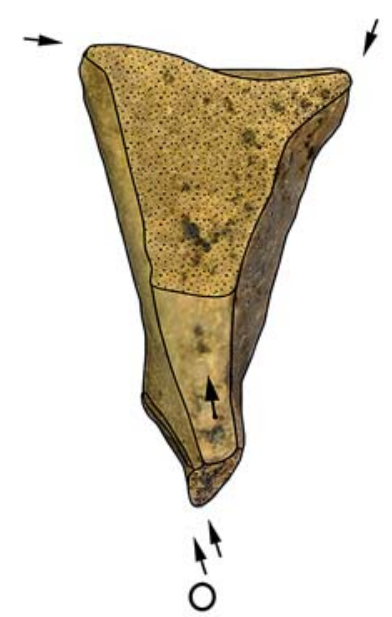

5

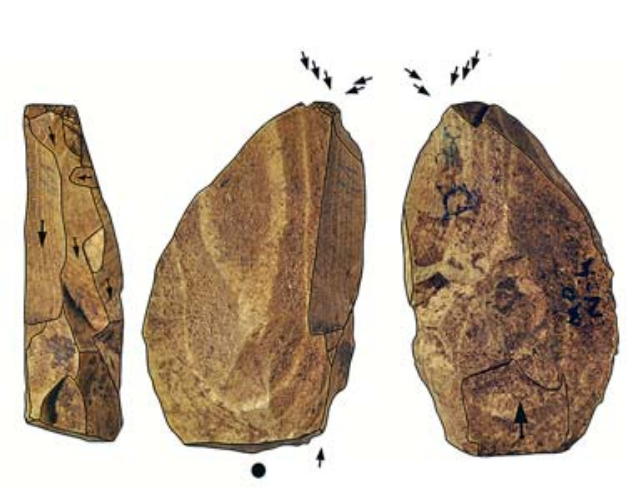

6

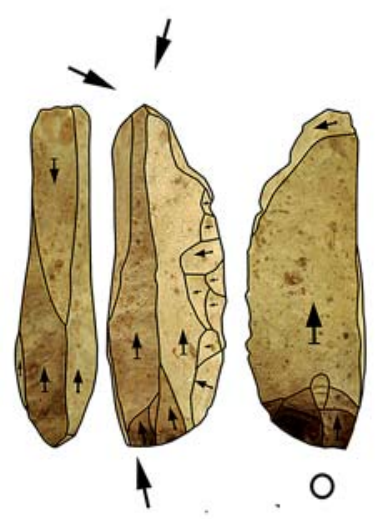

7

Fig. 9. 1: Multidirectional Flake core, 2: Splintered Piece, 3: Pyramidal Bladelet Core, 4 - 7: Burin Cores. 
While complete core tablets are rare $(n=2)$, the largest group in contrast comprises partial core tablets $(n=$ 33, Fig. 5: 18). Although the reduction of core tablets provides one opportunity to maintain the right angle in renovating the striking platform, preparing the striking edge by reducing smaller platform rejuvenation blanks $(n=36)$ is another and well-documented method (cf. INIZAN et al. 1992). However, traces of this morphology also occur during the observed $90^{\circ}$ degree shift in the striking direction, while the former edge serves as the crest for further reduction (Fig. 5: 17). This mode could also be used when trimming the lateral sides of the core, a technological stage that is regularly documented in sites with intensive knapping activity and complete on-site reduction sequences (e.g. Bolinkoba, BRADTMÖLLER 2014; Aitzbitarte III ext., DE LA PEÑA 2012; Prado, SAENZ BURUAGA et al. 2005).

An additional 40 artefacts resulted from knapping accidents. Among these, the most frequent accidents resulted from a minimal degree of core trimming and the adverse convexity of the reduction surface. This is especially visible from the large amount of plunging flakes ( $n=28$; Fig. 5: 21). All described causes for this failure are present in the assemblage, including the reduction of a cortex-covered end, the distal part of a pyramidal core and an opposite striking platform (cf. INIZAN et al. 1992). Analysis of their size and cortex cover suggests that these accidents happened throughout the complete reduction sequence. Furthermore, eight pseudo-burins (burins de Siret) and three languette fragments (Fig. 5: 19, 20) are present. While burins de Siret are typical markers for direct hard hammer percussion, languette fragments usually appear due to the direct or indirect soft hammer impact. While the latter is only visible on blades, burins de Siret are present on blades and flakes.

\subsection{Percussion techniques}

Characteristics of the proximal artefact end mostly reveal the patterns documented on cores. Only a small number of butts exhibit cortex $(12.5 \%, 10 \%$ and $0 \%$ for characteristic debitage, blades and bladelets, respectively), which reflects the low proportion of cortex documented for the whole assemblage. Most artefacts exhibit a flat butt (blades: $85.7 \%$, bladelets: $100 \%$ ) that is associated with the observed simple preparation of the striking platform. Dorsal reduction of the platform edge, mainly necessary for direct soft hammer reduction, was occasionally practiced on characteristic debitage (11.7\%), but is regularly observed among blades (34.4\%) and bladelets (38.5\%). The usual use of direct soft hammer percussion for the laminar blanks is also suggested by a predominant oval butt, with 34.5\% of the bladelets and $31.3 \%$ of the blades showing a characteristic lip ( $\sim 80 \%$ of the oval-shaped butts). This corresponds to hinge (16.6\%) and step fractures (5.6\%) documented on blades (INIZAN et al. 1992) and is supported by the value of the QS index. This index is a simplex way to set butt and artefact size in relationship, to assess the kind of percussion used (SCHÖN 1996). With a QS index value of 5.1, the assemblage is situated within the supposed range of direct soft hammer percussion $(>5<7)$.

In contrast, irregularly shaped butts (30.4\%) dominate the artefacts of characteristic debitage. Furthermore, they exhibit fewer hinge fractures $(7.8 \%)$, but show percussion marks (5.6\%), which are missing for the laminar blanks. Nonetheless, with $29.8 \%$ showing an oval butt shape and $25.8 \%$ having percussion lips, artefacts from the rejuvenation of platforms appear to have been regularly reduced by means of a direct soft hammer impact.

\subsection{Raw material composition and the lithic re- duction pattern}

Although the previous sections provided a general summary of lithic exploitation strategies, it is also necessary to discuss raw material usage to gain a better understanding of import/export processes and the possible selection/adaptation practices between reduction schemes and raw materials. The first point refers to a difference between reduction of flint and non-flint (i.e. quartzite and quartz) for the intended blanks. Laminar cores are only made of flint, and a similar pattern is visible for the blanks; $92.9 \%$ and $100 \%$ of blades and bladelets are made of flint, respectively. While some blades/blade-like flakes were made of quartzite, their reduction can be classified due to their negatives as embedded within the general flake exploitation strategy. This is a pattern regularly observed during the Gravettian (cf. CALVO et al. 2015; BRADTMÖLLER et al. 2015B). While most of the artefacts from core trimming processes are made of flint, a rejuvenation blank made of quartzite and a partial core tablet of quartz are preserved. However, their small number implies that these actions played a minor role in exploitation strategies. Instead, the large core sizes, high cortex coverage and the absence of exhausted cores imply a more opportunistic production of flakes and an early discard of these materials.

For analysing the different flint classes more precisely, the debris is excluded due to the difficulty in classifying the raw materia (Tab.3). Results show an overall percentage for allochthonous flint (Treviño and Flysch) of 21.3\%. Cores made on external flint varieties show an above-average value of $47.4 \%$, while exhausted cores show a slightly lower value at $30.0 \%$. Laminar blanks are often made of exogenous flint (48.6\% for blades, $56.7 \%$ for bladelets and $29.0 \%$ for burin spalls). Characteristic debitage like rejuvenation blanks (41.1\%) or partial core tablets (42.4\%) are also more frequently made of non-local raw materials. Some are modified, but most are unretouched. This supports the hypothesis that these blanks were reduced on-site and were not regularly imported. Second, this reflects a higher level of core maintenance for exotic raw materials. Furthermore, the below-average weight of documented exhausted cores (43 g) and flake cores (160 $\mathrm{g}$ and $98 \mathrm{~g}$ ) indicate a high exploitation value for the Basque Treviño flint. In contrast, no clear pattern is evident for the Flysch, perhaps caused by the better availability of this variety as seen in the higher quantity of artefacts made from this flint. Only $4.3 \%$ of the 


\begin{tabular}{|c|c|c|c|c|c|c|c|}
\hline & & $\begin{array}{c}\text { Indeterminate } \\
\text { Chert }\end{array}$ & Flysch & Treviño & Quartz & Quartzite & Total \\
\hline \multirow[t]{2}{*}{ flake(0) } & count & 1202 & 167 & 91 & 38 & 129 & 1627 \\
\hline & $\%$ within raw material & 84,0 & 57,0 & 56,9 & 86,4 & 83,8 & 77,3 \\
\hline \multirow[t]{2}{*}{ flake(1) } & count & 9 & 4 & 0 & 0 & 0 & 13 \\
\hline & $\%$ within raw material & 0,6 & 1,4 & 0,0 & 0,0 & 0,0 & 0,6 \\
\hline \multirow[t]{2}{*}{ flake(2) } & count & 44 & 27 & 8 & 4 & 6 & 89 \\
\hline & $\%$ within raw material & 3,1 & 9,2 & 5,0 & 9,1 & 3,9 & 4,2 \\
\hline \multirow[t]{2}{*}{ Blade $(0)$} & count & 46 & 25 & 15 & 1 & 6 & 93 \\
\hline & $\%$ within raw material & 3,2 & 8,5 & 9,4 & 2,3 & 3,9 & 4,4 \\
\hline \multirow[t]{2}{*}{ Blade(1) } & count & 4 & 7 & 5 & 0 & 0 & 16 \\
\hline & $\%$ within raw material & 0,3 & 2,4 & 3,1 & 0,0 & 0,0 & 0,8 \\
\hline \multirow[t]{2}{*}{ Blade(2) } & count & 12 & 14 & 4 & 0 & 3 & 33 \\
\hline & $\%$ within raw material & 0,8 & 4,8 & 2,5 & 0,0 & 1,9 & 1,6 \\
\hline \multirow[t]{2}{*}{ Bladelet(0) } & count & 11 & 5 & 2 & 0 & 0 & 18 \\
\hline & $\%$ within raw material & 0,8 & 1,7 & 1,3 & 0,0 & 0,0 & 0,9 \\
\hline \multirow[t]{2}{*}{ Bladelet(1) } & count & 2 & 3 & 4 & 0 & 0 & 9 \\
\hline & $\%$ within raw material & 0,1 & 1,0 & 2,5 & 0,0 & 0,0 & 0,4 \\
\hline \multirow[t]{2}{*}{ Bladelet(2) } & count & 0 & 1 & 2 & 0 & 0 & 3 \\
\hline & $\%$ within raw material & 0,0 & 0,3 & 1,3 & 0,0 & 0,0 & 0,1 \\
\hline \multirow[t]{2}{*}{ Burin spall(0) } & count & 37 & 7 & 6 & 0 & 5 & 55 \\
\hline & $\%$ within raw material & 2,6 & 2,4 & 3,8 & 0,0 & 3,2 & 2,6 \\
\hline \multirow[t]{2}{*}{ Burin spall(1) } & count & 1 & 4 & 0 & 0 & 0 & 5 \\
\hline & $\%$ within raw material & 0,1 & 1,4 & 0,0 & 0,0 & 0,0 & 0,2 \\
\hline \multirow[t]{2}{*}{ Burin spall(2) } & count & 5 & 2 & 1 & 0 & 1 & 9 \\
\hline & $\%$ within raw material & 0,3 & 0,7 & 0,6 & 0,0 & 0,6 & 0,4 \\
\hline \multirow[t]{2}{*}{ Core trimming $(0)$} & count & 35 & 16 & 10 & 1 & 1 & 63 \\
\hline & $\%$ within raw material & 2,4 & 5,5 & 6,3 & 2,3 & 0,6 & 3,0 \\
\hline \multirow[t]{2}{*}{ Core trimming(1) } & count & 1 & 0 & 1 & 0 & 0 & 2 \\
\hline & $\%$ within raw material & 0,1 & 0,0 & 0,6 & 0,0 & 0,0 & 0,1 \\
\hline \multirow[t]{2}{*}{ Core trimming(2) } & count & 2 & 4 & 1 & 0 & 0 & 8 \\
\hline & $\%$ within raw material & 0,1 & 1,4 & 0,6 & 0,0 & 0,0 & 0,4 \\
\hline \multirow[t]{2}{*}{ Knapping accidents(0) } & count & 19 & 6 & 9 & 0 & 3 & 37 \\
\hline & $\%$ within raw material & 1,3 & 2,0 & 5,6 & 0,0 & 1,9 & 1,8 \\
\hline \multirow[t]{2}{*}{ Knapping accidents(1) } & count & 0 & 0 & 0 & 0 & 0 & 0 \\
\hline & $\%$ within raw material & 0,0 & 0,0 & 0,0 & 0,0 & 0,0 & 0,0 \\
\hline \multirow[t]{2}{*}{ Knapping accidents(2) } & count & 1 & 1 & 1 & 0 & 0 & 3 \\
\hline & $\%$ within raw material & 0,1 & 0,3 & 0,6 & 0,0 & 0,0 & 0,1 \\
\hline
\end{tabular}

Tabla 3: Quantity and \% within raw material for the different blank types: $0=$ unmodified, $1=$ projectile, $2=$ domestic tools.

artefacts made on indeterminate (local) flint are blades, while this amount increases rapidly for Treviño (15.0\%) and Flysch (15.7\%). A similar pattern is evident among bladelets, suggesting that laminar production was of greater importance for this high-quality raw material.

A further interesting pattern observed between the different flint types involves the striking direction. This is primarily unidirectional, but as mentioned before, bidirectional patterns are also observed for the cores and blanks. However, the question arose, if the observed uni- and bidirectional schemes were related to different reduction stages? While no significant connection could be documented between the amount of cortex and the direction of dorsal negatives, the artefact size was analysed. With the degree of fragmentation relatively high, the width and thickness were here fore evaluated. Thus, an interesting configuration is evident: blades with unidirectional negatives are on average $12 \mathrm{~mm}$ wide and $5 \mathrm{~mm}$ thick, while bidirectional ones are slightly larger (width $\mathrm{AM}=14 \mathrm{~mm}$ ) and (thickness $A M=7 \mathrm{~mm}$ ). This pattern seems to result from alternating reduction strategies (Tab. 4). Blades made of indeterminate flint are small in size $(10 \mathrm{~mm}, 5 \mathrm{~mm})$ and only $13.3 \%$ show bidirectional negatives. Blades made of Treviño flint are comparable in size $(11 \mathrm{~mm}, 4 \mathrm{~mm})$ and only exhibit unidirectional reduction. In contrast, specimens made of Flysch are bigger (14 mm, $6 \mathrm{~mm}$ ) and are more often bidirectional reduced (25.8\%). This suggests a more regular need for bidirectional maintenance of the convexity among the bigger raw nodules or a higher intensity curation of the exotic raw material.

The study of the quality of target products is unfortunately limited to the blades due to the poor preservation rate and quantity of bladelets (Tab. 4). Assuming that long blanks with small widths and thicknesses were preferred 


\begin{tabular}{|c|c|c|c|c|c|c|c|}
\hline \multirow{5}{*}{$\begin{array}{l}\text { Chert } \\
\text { Indeterminate }\end{array}$} & & Mean & Median & CV & MAX & MIN & Tota \\
\hline & Length & 32.2 & 28 & 39.58 & 62 & 18 & 9 \\
\hline & Width & 10.4 & 10 & 31.2 & 17 & 8 & 30 \\
\hline & Thickness & 4.9 & 4 & 53.5 & 13 & 3 & 30 \\
\hline & $\begin{array}{l}\text { Quality Index = } \\
\text { (Width X } \\
\text { Thickness) / } \\
\text { Length) }\end{array}$ & 1.6 & & & & & \\
\hline \multirow{4}{*}{ Flysch } & & Mean & Median & CV & MAX & MIN & \\
\hline & Length & I & I & I & I & I & 3 \\
\hline & Width & 14 & 13 & 28.4 & 21 & 8 & 20 \\
\hline & Thickness & 5.8 & 5 & 51.8 & 16 & 3 & 20 \\
\hline \multirow{4}{*}{ Treviño } & & Mean & Median & CV & MAX & MIN & \\
\hline & Length & 1 & I & I & I & I & 1 \\
\hline & Width & 11.3 & 10.5 & 30.4 & 18 & 8 & 6 \\
\hline & Thickness & 3.5 & 3.5 & 29.9 & 5 & 2 & 6 \\
\hline \multirow{4}{*}{ Quartzite } & & Mean & Median & CV & MAX & MIN & \\
\hline & Length & I & I & I & I & I & 3 \\
\hline & Width & 15.6 & 16 & 30.5 & 22 & 9 & 7 \\
\hline & Thickness & 8.4 & 9 & 45.4 & 15 & 4 & 7 \\
\hline
\end{tabular}

Tabla 4: Blade dimension.

by Palaeolithic flintknappers, calculating width $x$ thickness/length results in an index of 1.6, which points to a high blade quality (KAANEGARD-NIELSEN 1985, in HARTZ 1999). This value is comparable to the Level $F$ assemblage at Bolinkoba, where blade production was the primary laminar exploitation strategy (BRADTMÖLLER 2014). The analysis of parallel edges after Bauche (1987) also support this result. Hereby the value of parallelism is identified by the quantity of squares the edges of an artefact are cutting (Fig. 10). Among 80 blades documented with preserved edges, $46.5 \%$ blades are only penetrating six or seven squares, which can be interpret as a high value of parallelism within the assemblages (Fig. 10). Some differences are evident between the raw material classes. While 69.2\% of Treviño blades show a high standardisation in relationship to parallelism (six or seven squares), only one quartzite blade (14.2\%) reflects this quality; a better value is given for the Flysch blades (56.6\%) and the local flint (37.8\%). This likely reflects better control of the blank shape when using distinct laminar reduction strategies as well as a higher quality raw material.

Besides the blade-bladelet reduction on prismatic/pyramidal cores, carinated elements document a distinctive microlaminar reduction sequence. Two sets of two burin cores are made of Treviño flint and a local variety (Tab. 3). For the latter set, the first morphology was likely influenced by a platelike natural shape, whereas the second example shows an intensive, multidirectional reduction. The examples of Treviño

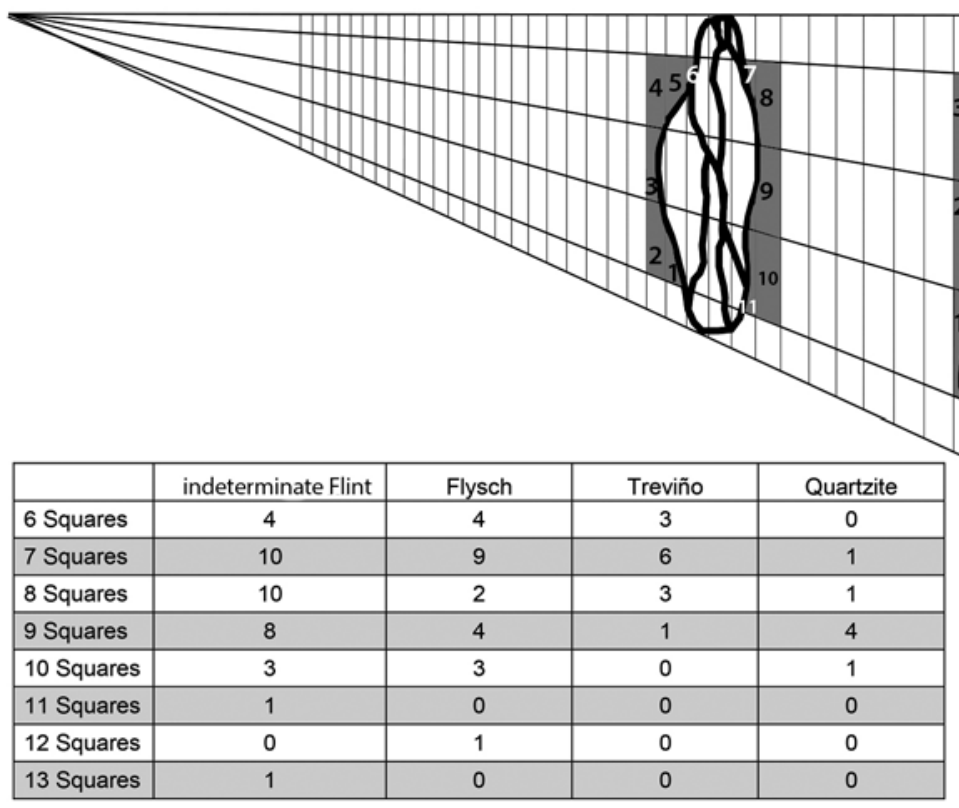

Fig. 10. Measurement result of the blade parallelism (after Bauche 1987), after raw material classes. $6=$ parallel lateral edges, $13=$ irregular lateral edges. 
flint were formerly large flakes. One exhibits a former lateral retouch, supporting its secondary use as a core, possibly based on the high-quality raw material. The other specimen exhibits a partial reduction of the ventral surface and a small, retouched striking platform, both characteristics of Rayssian burins (KLARIC 2007). Both Treviño cores exhibit similar characteristics regarding mean length, width and thickness (AM $=34.5 \mathrm{~mm}, 16.5 \mathrm{~mm}, 8.0 \mathrm{~mm}$, respectively) to burin cores made of exotic raw material from the Gravettian site of Cueto de la Mina (AM = $36.3 \mathrm{~mm}, 19.5 \mathrm{~mm}, 9.0 \mathrm{~mm}$, respectively) (BRADTMÖLLER et al. 2015b). While the burin cores in Cueto de la Mina were interpreted as a component of a personal mobile toolkit for standardised laminar production, these pieces could have served the same function. Therefore, note that the documented carinated laminar core from Level 4 of Cueva Morín is also made of Treviño flint and perhaps served a similar function (Fig. 8: 5).

\section{4.- THE TOOL ASSEMBLAGE}

In total, $5.5 \%$ of artefacts $(n=210)$ in the assemblage show traces of further tool modification. This is a relatively low percentage, but comparable to other modern excavated sites like La Viña (MARTíNEZ AND SANTAMARÍA 2013). For further analysis and better comparison, the toolkit was divided into three main groups: projectiles ( $\mathrm{n}=$ $54)$, burins ( $n=57)$ and pieces from the domestic sphere of activities ( $n=99$ ); the latter group was further divided into six subgroups.

\subsection{Projectiles}

Artefacts classified as 'projectiles' bear a backed edge or exhibit an intentionally pointed morphology (cf. Moreau 2009) (MOREAU 2009). Therefore, this group contains distinct Gravettian fossiles directeur like Gravette points or microgravettes (BREUIL 1912) as well as simple backed pieces. This class reveals a high fragmentation rate with no, thus exhibiting a heterogeneous morphology. There- fore, the final classification of these artefacts was not always possible. A total of 17 pieces could be assigned typologically (Fig. 5: 1-10), including four Gravette points, ten microgravettes, one double-backed piece and two simple points. Of the modified blanks, the Gravette points are the most homogenous, only made on blades lacking traces of cortex. Microgravettes were made on small blades and bladelets, whereas one piece was also made on a partial core tablet.

An interesting artefact is a modified burin spall (Fig. 5: 10). This fragment exhibits retouch on both lateral sides, one dorso-ventral backed edge and one semi-abrupt edge. Classification as a microgravette is unlikely, as the piece indicates more similarities to the double-backed laminar blanks known from Vale Boi or Cueto de la Mina (MARREIROS 2014; BRADTMÖLLER et al. 2015b). A further unusual artefact is a rejuvenation blade, on which unilateral backed retouch shapes the proximal end and semi-abrupt retouch on the other side forms a notch, resulting in a thinned proximal end (Fig. 5: 8). This could correspond to a description by Echegaray and Freeman (1971: 292), in which '[...] some notched pieces look a bit like Font-Robert point bases, but are not sure to be bits of such pieces'. One additional blade fragment made of mountain crystal shows unilateral retouch and a pointed distal end (Fig. 5: 9). Although typological classification as a fléchette fragment is not possible, two burin-like impact fractures nonetheless suggest its use as a projectile. The appearance of impact fractures is seen among many artefacts within this group, supporting their interpretation as projectile implements (SANO 2009, 2012; SANO AND OBA 2015; but for a critical discussion, see ROTS AND PLISSON 2014).

Thirty-eight artefacts show a backed edge without a characteristic morphology. Some were only partially backed, which could be interpreted as a discarded preform or a tool for an unknown purpose (Fig. 5: 11). Not surprisingly, the artefacts show great variations concerning their width: thickness ratios. Gravette points, microgravettes and bac-

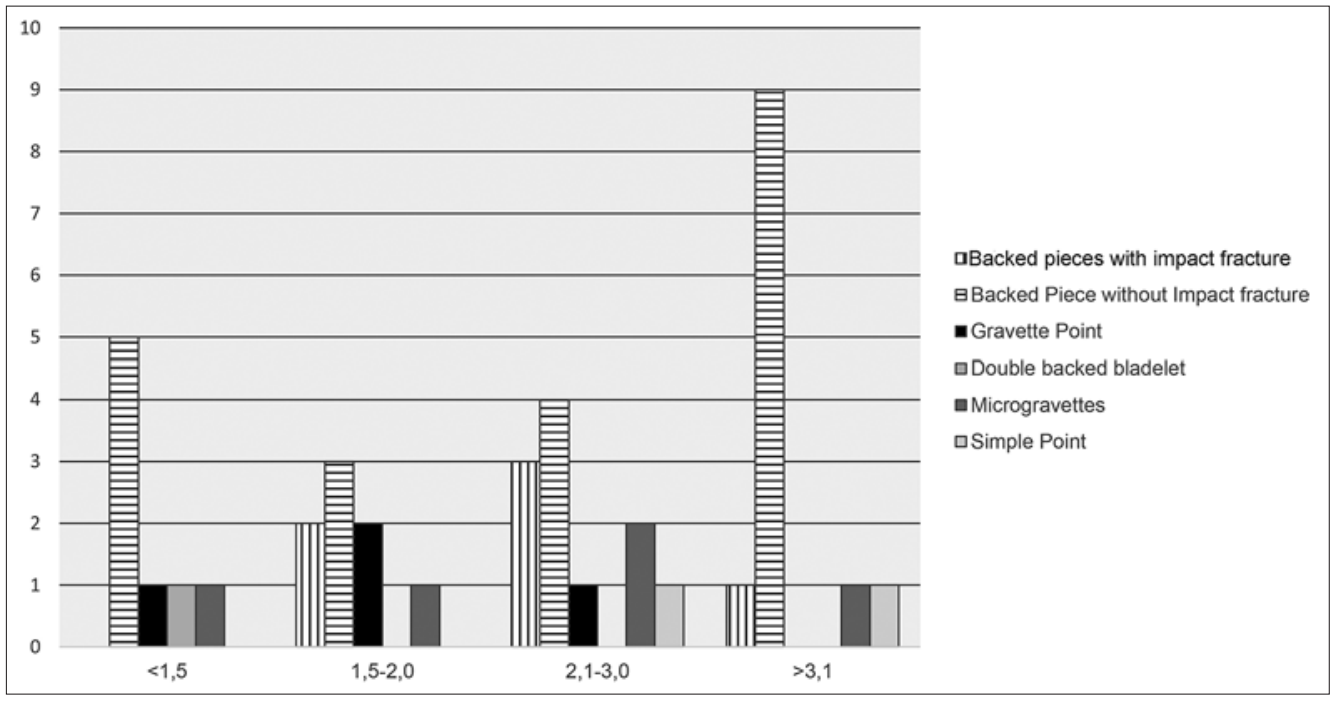

Fig. 11. Width-thickness ratio of the different tool types classified as projectiles. 
ked pieces with impact fractures exhibit a thickness between $2 \mathrm{~mm}$ and $5 \mathrm{~mm}$ and an index below 3.1, which may suggest a standardised hafting arrangement (WIERER 2013). In contrast, over $50 \%$ of the backed pieces without impact fractures show a width/thickness ratio of 3.1 or higher, suggesting their unlikely use as projectiles.

In addition, one microgravettes and one backed artefact with a supposed impact fracture show a similar high ratio. These support the general statement that functionality of this class can not be easily assigned by its morphology. Many pieces could have served as a knife implement or were used for multiple proposes (cf. HARROLD 1993; TALLER et al. 2012). Nonetheless, a recently conducted usewear analysis of one backed artefact from this assemblage has verified the impact character of the burin-like fractures and could document further impact damage on one lateral edge (U. Perales, personal communication). Thus, several of these projectiles likely indicate human activity related to hunting, while the high amount of fragmentation and the characteristic impact traces point to a general discard/maintenance stage. However, additional research is necessary to specify their quantity.

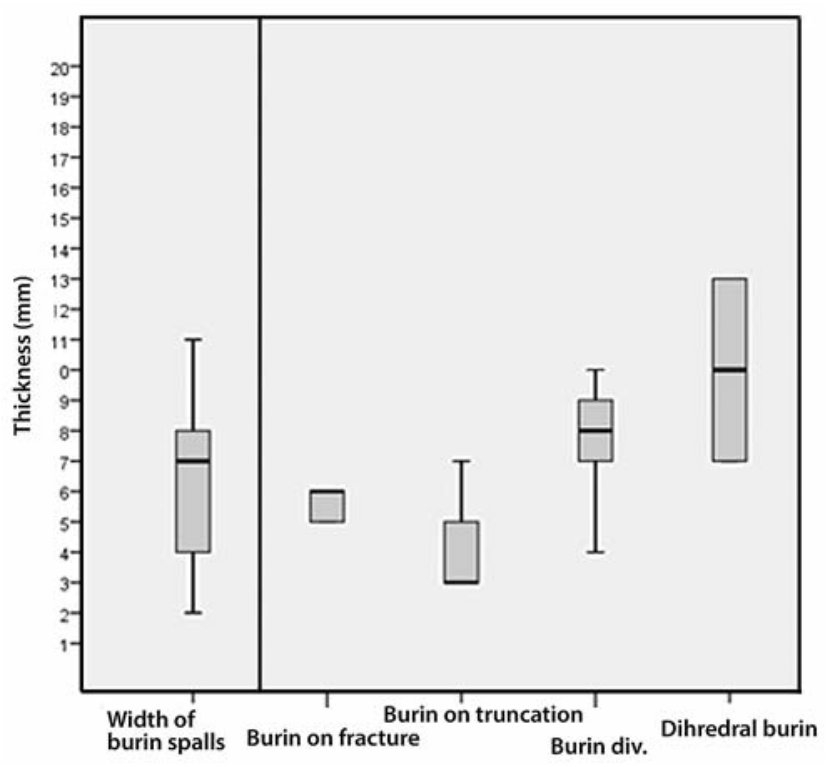

Fig. 12. Boxplot of the average thickness for the main Burin types in regard to the average width of the Burin spalls. (Quantities: Dihedral burin $=4$, Burin diverse $=20$, Burin on truncation $=8$, Burin on fracture $=7$, Burin spall: 47 ).

\subsection{Burins}

The 57 documented burins can be considered quite heterogeneous in terms of morphology (and most likely function). The most numerous class is the 'burin diverse' $(n=25)$, which is morphologically indeterminate. These artefacts were made mostly of flakes (61.9\%) and blades (33.3\%); one example is made on a rejuvenation flake. Two characteristics of this group are their large size and the small number of additional modifications. With an average length of $31 \mathrm{~mm}$ and a width of $18 \mathrm{~mm}$, they represent the biggest dimensions of all burin types. Length and width exhibit great variation, while the thickness $(A M=8$ $\mathrm{mm}$ ) shows only minimal variance. A similar distribution is also visible for the dihedral burins $(n=8)$, which are made on big flakes (62.5\%), artificial waste (25\%) and one partial core tablet. Burins on fractures $(n=11)$ show a similar blank pattern dominated by flakes (82.5\%) and blades $(17.5 \%)$. Burins on truncations $(n=9)$ are artefacts with a convex or straight truncated burin platform. While none of these truncations in Level 4 exhibit macroscopic visible usewear traces, they may have only served as striking platforms. Flakes (75\%) and blades (25\%) functioned as blanks.

For understanding the relationship between burins and the origin of the documented burin spalls, the thickness of burins and the width of burin spalls were compared (Fig. 12). Although the thickness can only describe the maximal width of the potential burin spall, a similar range is nonetheless of interest. With an average width of $7 \mathrm{~mm}$, burin spalls exhibit a dimension comparable to 'burins diverse' ( $\mathrm{AM}=8 \mathrm{~mm}$ ) and dihedral burins $(A M=10 \mathrm{~mm})$.

\subsection{Domestic tools}

This group contains a wide range of modifications reflecting an even larger variety of performed activities, e.g. food, bone and antler processing. Comprising 99 artefacts, this is the biggest tool type class within the assemblage. Based on the cultural affiliation and duration of site occupation, some artefacts exhibit a longer biography of use with several modifications visible. Therefore, their size and amount of cortex are of special interest for positioning the artefacts within the reduction sequence, while their blank types provide information about the general selection process.

\subsubsection{Lateral retouched pieces}

This category ( $n=38$ ) comprises the highest number of artefacts. Due to their low ranking within the hierarchy of tool classification (DRAFEHN et al. 2008), these pieces normally exhibit only one modification. This could probable be the factor behind their average length of 27 $\mathrm{mm}$, the highest among all tool types (Tab. 5). Their lateral retouch is often straight $(n=19)$ or convex-shaped in eight specimens. Five of these are large, cortex-covered flakes that could be classified as scrapers. Furthermore, four have concave edges and the shapes of six artefacts could not be classified. Twenty tools (66.6\%) are made on flakes, but many are also made on laminar blanks (33.3\%), perhaps based on the need for long cutting edges. Although no possible residues were observed on these artefacts, the direct handling of the stone tool was most likely. Thus, it is not unexpected that half of these pieces $(n=19)$ retain cortex. 


\begin{tabular}{|l|l|c|c|c|}
\hline & & $\begin{array}{c}\text { Length } \\
\text { (in mm) }\end{array}$ & $\begin{array}{c}\text { Width } \\
\text { (in mm) }\end{array}$ & $\begin{array}{c}\text { Thickness } \\
\text { (in mm) }\end{array}$ \\
\hline Lateral Retouch & count & 27.1 & 18.8 & 7.8 \\
\hline & coefficient of variation & 42.1 & 48.8 & 57.4 \\
\hline Borer & count & 21 & 19 & 7.5 \\
\hline & coefficient of variation & 12.9 & 43.6 & 44.2 \\
\hline Endscraper & count & 24.8 & 20 & 8.1 \\
\hline & coefficient of variation & 30.1 & 33.9 & 14.3 \\
\hline Truncation & count & 23.3 & 19.6 & 7.5 \\
\hline & coefficient of variation & 31.5 & 29.9 & 47.1 \\
\hline Splintered Pieces & count & 30.7 & 19.7 & 10.1 \\
\hline & coefficient of variation & 15.1 & 30.6 & 28.7 \\
\hline MT & count & 26.8 & 14.4 & 5.8 \\
\hline & coefficient of variation & 34.6 & 38.9 & 49.8 \\
\hline
\end{tabular}

each blade and plunging flake). As expected, they exhibit a high thickness value $(8.1 \mathrm{~mm})$, indicating a very low coefficient of variation pointing to intentional selection by humans.

\subsubsection{Truncations}

Twelve pieces are classified as truncations, with five straight and seven convex shapes. Concave truncations, characteristic of Noailles burins, are not documented. Nine pieces are made on flakes and three on blades. In contrast to the endscrapers, fewer pieces show cortex (n $=4,>33 \%$ ). Their size is quite average and no special selection could be observed.

Tabla 5: Dimension for the tool types.

\subsubsection{Borers}

Ten pieces exhibit borer modification. They were commonly made on flakes (77.1\%), a burin spall (11.1\%) and a rejuvenation flake (11.1\%). Only two pieces show cortex, the lowest ratio of all domestic tools. The borer tip is in seven cases retouched from both sides, while among three examples one retouch sufficed due to a morphologically favourable shape. The thickness of the tip lies between 2 $\mathrm{mm}$ and $4 \mathrm{~mm}$, and the size distribution of the tools suggests a possible selection of very small fractured blanks.

\subsubsection{Endscrapers}

Six of these tools were documented within the assemblage, a much lower proportion compared to the 31 endscrapers documented by Echegaray and Freeman (1978) in this level. This could be explained by the alternating classification as carinated cores or concave truncations, as well as a different final classification in the tool classification hierarchy. Fifty percent of the endscrapers are covered with cortex and four of six specimens are made from flakes (one

\subsubsection{Splintered pieces}

The classes of splintered pieces are morphologically quite homogenous. While two could be identified as bipolar cores, the other 15 artefacts are morphologically indistinct concerning former function. With the exception of one core tablet, only flakes were used for these tools. These pieces reflect the highest average value for length $(30 \mathrm{~mm})$ and thickness $(10 \mathrm{~mm})$, whereas the coefficient of variance supports the idea of a selective process concerning these two values. This is unsurprising because they are the most affected dimensions.

\subsubsection{Artefacts with macroscopically visible traces of usewear (MT)}

Edge damage and very fine, but irregular retouch could be observed on 17 artefacts. Such modification can be interpreted as usewear traces. Sixteen examples show visible wear on the lateral edge. Thus, this group is the only one dominated by laminar blanks with only one partial core tablet and one rejuvenation blade, suggesting a more opportunistic selection. Perhaps because of the need for better handling, $54 \%$ of these pieces retain cortex.

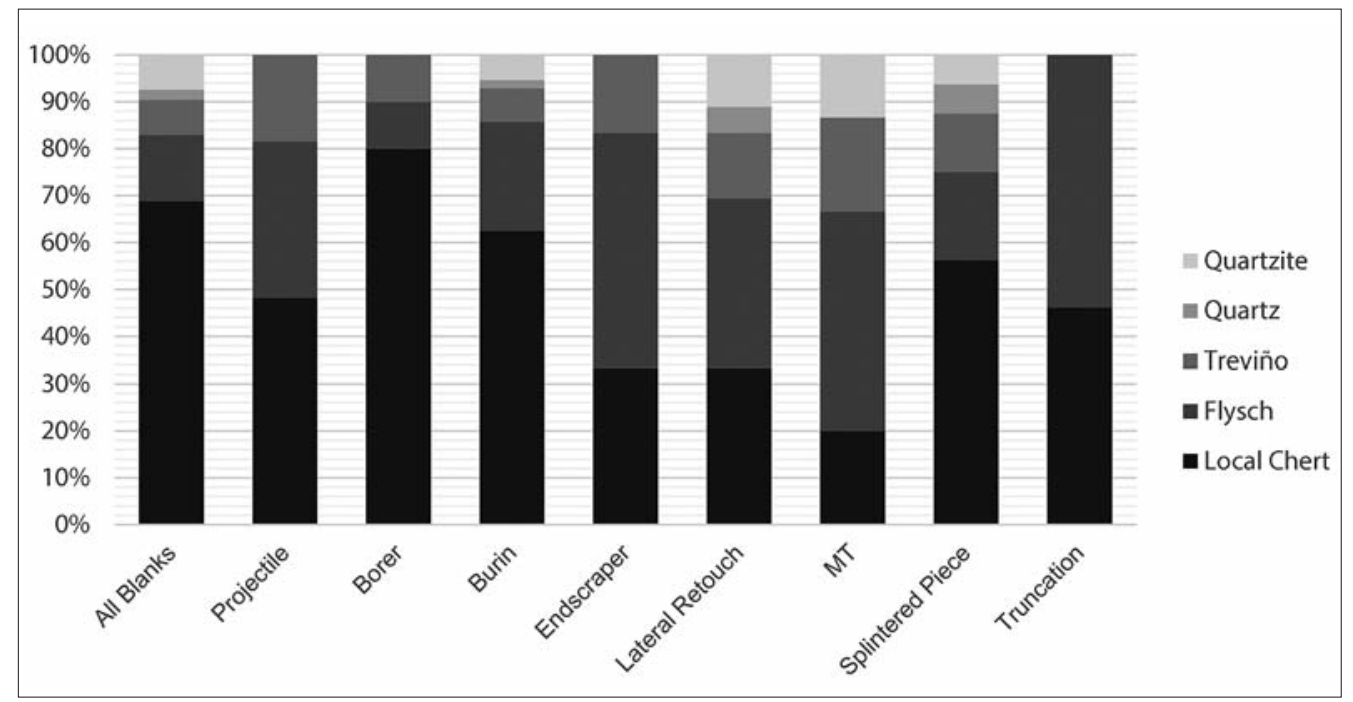

Fig. 13. Raw material composition of all blanks and for the different tool types (only all blanks $>1 \mathrm{~cm}$ ). 


\subsection{Chronological and cultural affiliations of the toolkit}

Although the toolkit of Level 4 provides a rich and distinctive picture, conclusions concerning the chronological or cultural affiliation are nonetheless limited and sometimes contradictory. This is caused both by the heterogeneity of the documented tool types and a missing chrono-typological subdivision for the Gravettian in Northern Spain (FOUCHER et al. 2008; BRADTMÖLLER et al. 2015a). Therefore, the classification of Echegaray and Freeman (1971) as Perigordian V/VI based on the quantity of keeled scrapers or dihedral burins cannot be verified (cf. ARRIZABALAGA AND DE LA PEÑA 2013). Moreover, the actual French system of subphases seems unapplicable here. The difficulty of using it becomes obvious considering the comprehensive record of different laminar production schemes and projectile types in Level 4. Some artefacts could be classified as Gravette points and microgravettes, types that are also present in other regional sites (microgravettes at Altamira, Gravette points at El Castillo). According to a recently published Gravettian subdivision (KLARIC et al. 2009), these pieces would suggest a generally younger age for Level 4. In contrast, the appearance of doublebacked artefacts is better known from early Gravettian assemblages (PESSESE 2006; MOREAU 2009; WIERER 2013; MARREIROS et al. 2015). This early attribution would also be supported by the Font Robert points, which were documented during the excavations of Vega del Sella (1921). Unfortunately, these artefacts are lost (DE LA PEÑA 2009). Concerning the burins, the general lack of the Noailles type is important to mention. While one artefact was formerly classified as an '[...] apparent Noailles Burin [...]' (ECHEGARAY AND FREEMAN 1971: 292), this could not be verified. Noailles burins are wellknown in the Basque Country (ARRIZABALAGA 1994) and Asturias (MARTÍNEZ AND SANTAMARÍA 2013). Furthermore, they appear in nearby El Castillo Cave, with one specimen published recently from Level 14 . Several more pieces were found in Levels 12 and 14 during the old excavation, but they are now lost (BERNALDO DE QUIRÓs et al. 2015). Thus, while known in the vicinity, the absence of these burins in Level 4 of Cueva Morín could be of chronological significance. Unfortunately, radiometric dates of Noailles burins in the Cantabrian region reflect all ages of the Gravettian (BRADTMÖLLER et al. 2015a; CALVO et al. 2015).

In summary, the tool composition from Level 4 reflects the more general picture of Gravettian assemblages in the province of Cantabrian and the Cantabrian Region overall, whereas the typo-chronological aspects of the assemblage are dissimilar. The latter implies either the inappropriateness of the French classification system for the local/regional conditions, or a long time depth for the different occupation events. For the moment, the new and consistent ${ }^{14} \mathrm{C}$ dates of $23,640 \pm 190$ BP (Poz-66758) and 23,790 190 BP (Poz-66759) support the first hypothesis.

\subsection{Raw material selection and tool biography}

As previously shown, several selection processes can be suggested for the tools. These include patterns of blank selection like laminar blanks for projectiles, and flakes for burins and other domestic tools. Furthermore, a possible selection is evident for the amount of cortex (e.g. lateral retouched pieces, endscrapers) and size dimension (e.g. splintered pieces). Additionally, patterns relating to raw material become evident (Fig. 13). As stated before, blade production seems to be more intensively done with allochthonous, high-quality raw material, leading to a higher frequency of these flint varieties within the group of modified laminar blanks. In particular, laminar blades made of Treviño flint appear to be regularly selected for tool production (or represent frequently imported single artefacts made on this raw material). This pattern is also visible for the flakes; those made of Flysch flint were chosen for modification, likely based on the higher quality and bigger size of the raw nodules and blanks. Furthermore, quartzite and quartz flakes were frequently used for tools, especially for the domestic toolkit.

In the next step, all documented artefacts with a general raw material determination (including modified and unmodified blanks, but excluding chips, thermal waste and cores) should be considered as available blanks for possible modification. This results in a composition of $68.8 \%$ undetermined (local) raw materials, 14\% Flysch, 7.6\% Treviño, $7.3 \%$ quartzite and $2.1 \%$ quartz. Based on these results, the only tool type showing an above-average frequency/selection of local flint is the borer (80\%). All other tool classes show values lower than $68.8 \%$ with $33 \%$ for the lateral retouched pieces. The latter result is most likely caused by its high percentage of laminar blanks made of allochthonous flint. Nonetheless, the above-average use of exotic flint is also visible for the more flake-focussed domestic tools. While quartzite and quartz are often used for tools with lateral working edges, no projectiles were made from these materials. While only one simple point was made of high-quality mountain crystal, most are made of flint, showing a value of $50.9 \%$ for the exogenous varieties. While projectiles are generally assumed to be short-life tools (SHOTT 2002), the local discard of these allochthonous flint tools suggests a long travel distance (residential move) for off-site produced projectiles, or an above-average production of these pieces using imported standardised laminar cores.

Many artefacts in the domestic toolkit including the burins exhibit multiple working edges that were studied within the framework of the modification sequence approach (BRADTMÖLLER 2013). This method follows the 'operational chains' (RICHTER 1997; PASTOORS 2000; UTHMEIER 2004) and the concept of versatility (SHOTT 1986), measuring the number of task applications per artefact and transferring these into a general tag. However, note that two or more related modifications could have different intentions: to serve as a preform for the subsequent tool, or as distinctly used edges (HISCOCK 1996). Projectiles and borers were therefore excluded from the analysis, as their dif- 
ferent modifications (e.g. multiple retouched edges) shaped a specific morphology. In addition, the splintered pieces were excluded because they reveal only a low number of multi-task sequences and their tool character is questionable. While the latter is true for the burins as well, these are nonetheless included, as they are regularly geared for diverse tasks.

A total of 129 artefacts were analysed, showing a maximum of three working edges within a sequence and 208 working edges overall. To better understand this data, the 'reduction hypothesis' is of special interest. This assumes that with ongoing usage (i.e. number of working edges), the size of the artefact will decrease (DIBBLE 1988; RICHTER 1997). If this hypothesis is falsified, it could be explained by the specific selection of bigger blank sizes or the comprehensive export and import of blanks and tools. The verification of the reduction hypothesis in contrast, could suggest that most modification steps of the sequence took place on-site, based on the proposition that the uselife of an artefact does not involve more than 2-3 campsite changes (WENIGER 1991).

To evaluate the local representation of each modification step, a trend chart including the more complex sequences provides a good overview (Fig. 14). Separated in groups by their first working edge, the trend chart clarifies that all steps are represented within the assemblage. Furthermore, we see that specimens representing the first stages greatly outnumber the later stages. With an index of 1.6 for modifications per tool, the amount of long modification sequences is limited ( $n=3,2.3 \%)$, while the value of artefacts with two tasks in sequence $(30.5 \%)$ is intermediate compared to those from short-term occupations (526\%; BRADTMÖLLER 2014).

A second approach analyses the versatility between blades and flakes. The reduction hypothesis fits for the blades, but was falsified for the flakes. While blades are showing a slight increase in the modification number along with a decrease in size, large flakes also exhibit many working edges, whereas small modified flakes do not (Fig. 15). Of interest is that flakes of the size classes VII and IV are underrepresented. This can suggest that flakes of size classes $\mathrm{VI}$ and $\mathrm{V}$ were chosen for modifications, while the use of smaller flakes in contrast to blades was not intended. According to Grimes and Grimes (1985), SC VI can be interpreted here as the minimum functional length of flake tools in this assemblage. In contrast, the higher quantity of small multi-modified blades can be explained with the verified use of adhesive technology in this level and a possibly higher frequency of hafted artefacts for the more standardised blade assemblage.

The diverse raw materials also reflect different patterns (Fig. 16). As previously stated, Flysch and Treviño flints exhibit a higher selection rate for tools compared to blanks made of local flint, quartzite or quartz. Interestingly, this pattern is not applicable to the sequence of modified tool edges. Flakes of all flint varieties show an equally distributed modification pattern with a generally low level of single modifications between 44-49\% and a tool:blank ratio between 1.9 for Treviño and 1.5 for local flint. In contrast, only $19 \%$ of blades made on local flint show short sequences (1.9), while Flysch (1.6) and Treviño (1.8) flints exhibit values between $50 \%$ and $52 \%$. The high number of lateral retouched artefacts made of Flysch and Treviño flints may explain this pattern.

\section{5.- DISCUSSION}

The lithic assemblage of Level 4 provides an ideal dataset for analysing lithic exploitation strategies, raw material procurement, the typical toolkit and more general topics regarding the occupation span or primary activities occurring on-site. However, note that the attribute analysis conducted in this study has limited value. Furthermore, the assemblage itself represents only a small proportion of activities conducted in the cave overall. Nonetheless, important information could be obtained, showing paraIlels to Gravettian occupations in the entire Cantabrian region. The following text sheds light on further comparable aspects like lithic sourcing and technological organisation with a special focus on neighbouring occupations close to Cueva Morín.

\subsection{Patterns of lithic technological organisation in Cantabria}

The first important point involves the frequent use of flint, which dominates $92.5 \%$ of the lithic assemblage in Level 4. Interestingly, this is the highest value among the regional Gravettian sites such as El Castillo Level 12 (82.6\%) and Level 14 (47.1\%); El Mirón 128 (69.4\%); and Altamira Level 8 (75.1\%) (DE LAS HERAS et al. 2013; GONZÁLEZ MORALES AND STRAUS 2013; BERNALDO DE QUIRÓS et al. 2015). This can be explained by the favourable situation involving the (low quality) flint of Peña Carbarga within a $5 \mathrm{~km}$ vicinity, as well as varying patterns of mobility. The latter could be supported by the high percentage of allochthonous flint. A total of $21.3 \%$ comprise Treviño and Flysch flints, two varieties from outcrops positioned between ca. 50 and $110 \mathrm{~km}$ from the site. While only a few artefacts could be identified from the western area (Piloña flint), the main direction of exogenous flint transport iwas hypothetically east-west. This kind of long-distance transport of quality knapping material is also seen with Flysch type Kurtzia in El Castillo (BERNALDO DE QUIRÓS et al. 2015) and El Mirón (GONZÁLEZ MORALES AND STRAUS 2013) as well as among artefacts of undetermined Flysch in Altamira (DE LAS HERAS et al. 2013).

While the high percentage of locally knapped allochthonous flint provides hints about the high mobility of these human groups and the subsequent import of artefacts to the site, the best clue for possible export is the low number of blade cores $(n=1)$. This is due to the high number of blades made of allochthonous flint and wasted cores made of indeterminate flint. A comparable situation was documented in Altamira Level 8. Local knapping is supported there 


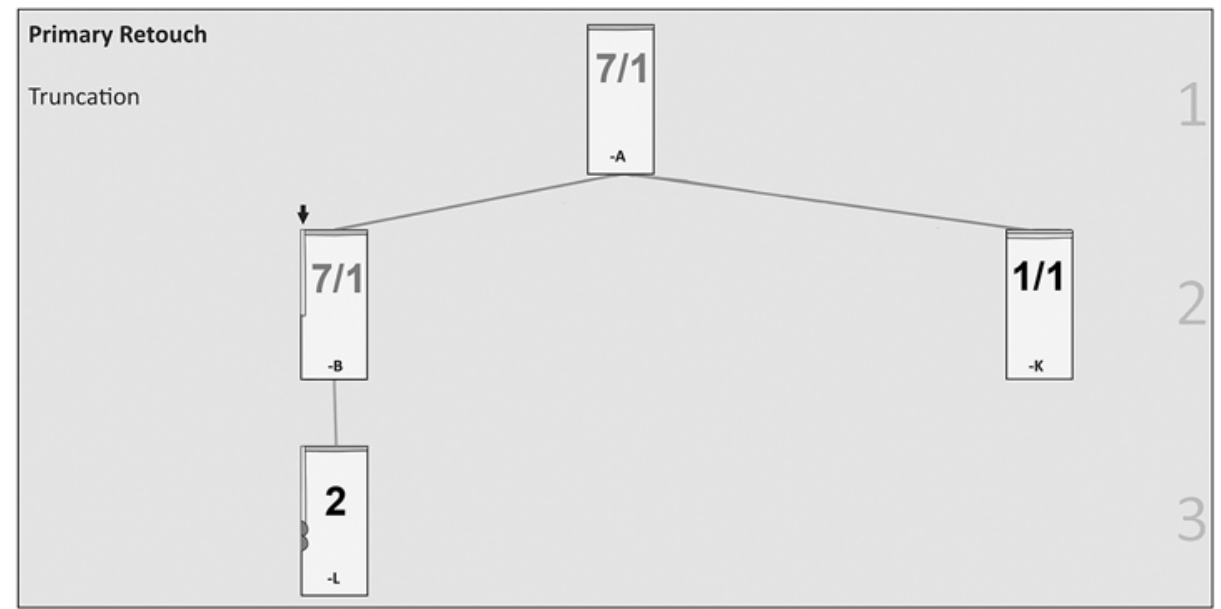

Primary Retouch

Endscraper
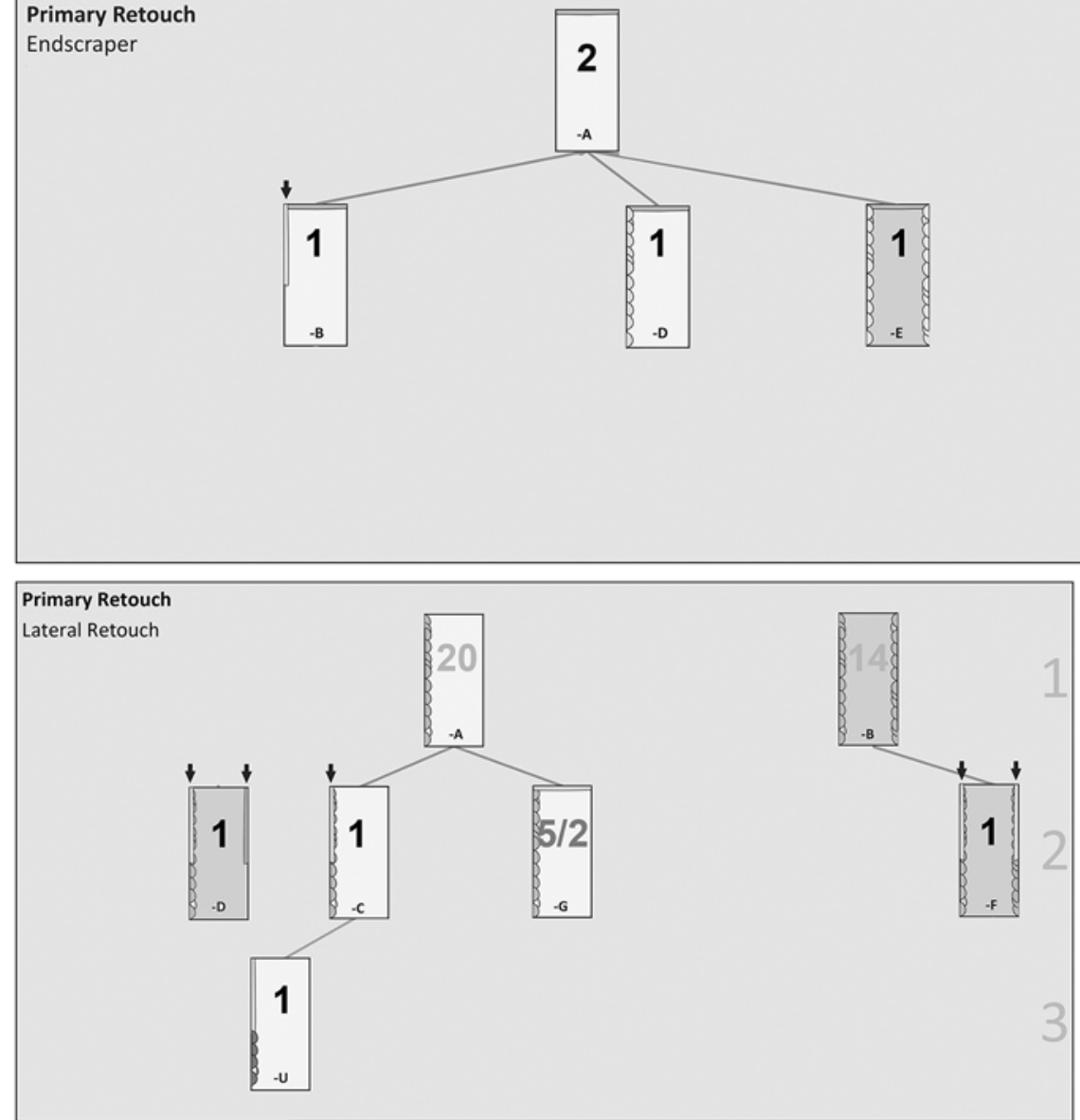

Primary retouch

Burin
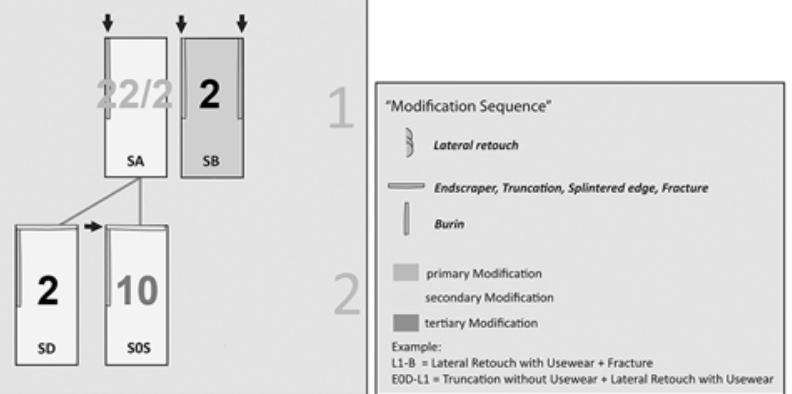

Fig. 14. Diagram of the modification sequences starting with a Truncation, Endscraper, Lateral retouch and a Burin. The numbers are showing the documented quantity of each modification stage. 


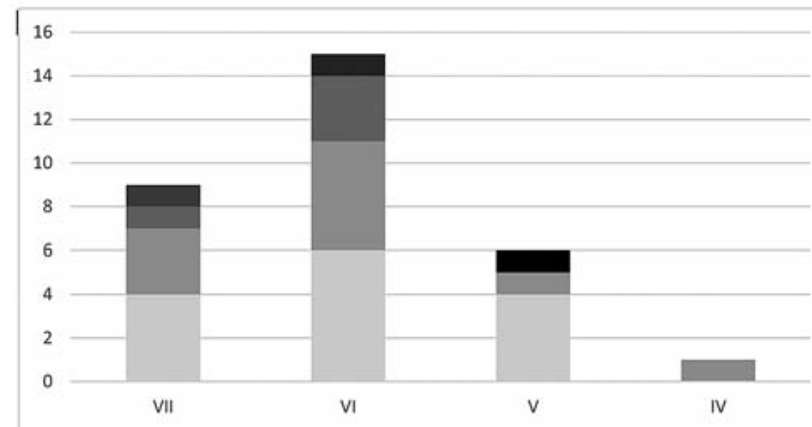

Blades

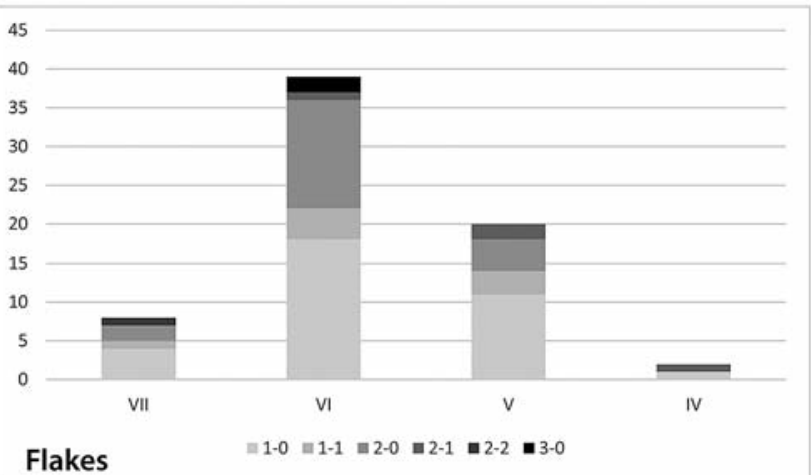

Flakes

Fig. 15. Number of artefacts per size class regarding to there number of modification steps (1-0: one single modification, 1-1: two modifications in a single sequences). Divided into Blades and Flakes.
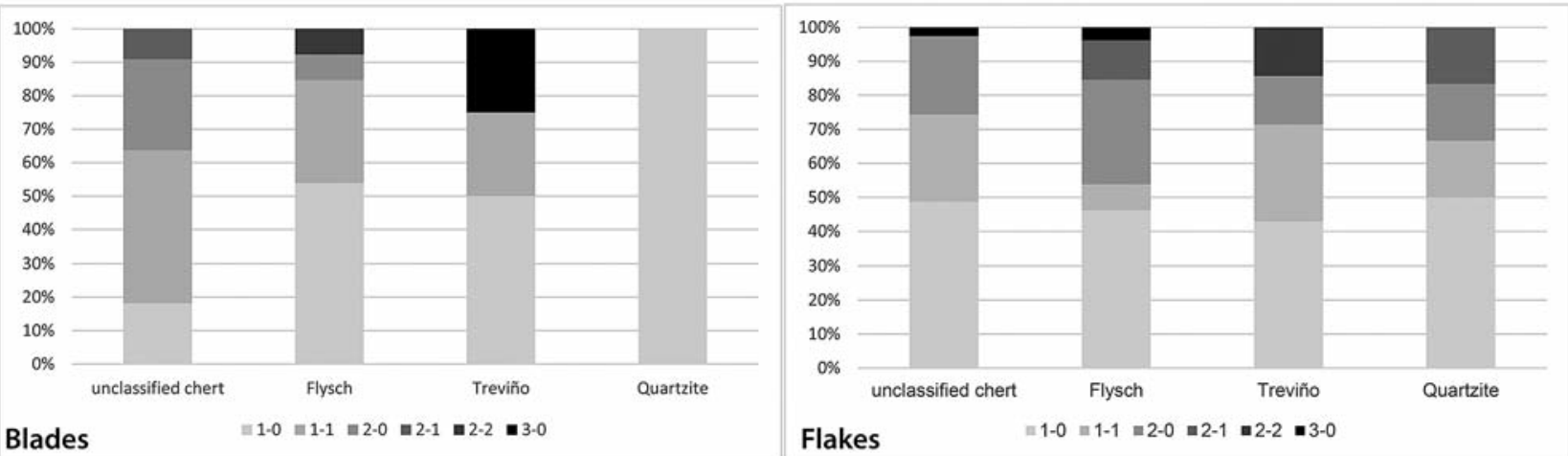

Blades

Flakes

Fig. 16. Number of artefacts per raw material unit to there number of modification steps (1-0: one single modification, 1-1: two modifications in a single sequences). Divided into Blades and Flakes.

by a lithic assemblage of 31 blades, 140 bladelets, 260 flakes and 1299 chips, but cores are missing completely. Although some bladelets could be reduced on the documented large dihedral burins, the export of laminar cores could also be suggested for this occupation.

Concerning lithic exploitation strategies, several schemes were observed in Level 4: uni- and bidirectional laminar reduction on prismatic cores; microlaminar reduction on pyramidal cores and laminar reduction on burin cores and carinated cores; and two artefacts classified as bipolar cores resulting from a bipolar anvil technique (DE LA PEÑA 2011). This reduction strategy is under discussion for some artefacts in El Castillo, as the Gravettian Levels show a similarly wide range of exploitation strategies (BERNALDO DE QUIRÓS et al. 2015).

Based on the blank:tool ratio, the laminar blanks of Level 4 can be interpreted as the primary target product for lithic exploitation. Nonetheless, nearly $50 \%$ of the tools were modified on flakes, suggesting a high demand for this blank type. This reflects the distinct flake production observed on flint and non-flint raw materials, resulting in discarded bi- or multidirectional flake cores. Distinct reduction schemes for laminar blanks were prismatic cores, pyramidal cores, carinated cores and large burin cores, which are only documented in flint. In contrast, we can reconstruct a minimal production of laminar blanks on non-flint materials within the general knapping strategy for flake production. This is an interesting point, as it suggests that the exploitation pattern of Cueva Morín is more similar to the flint-rich Basque Country than the western part of the Cantabria region (Asturias), where a distinct laminar/microlaminar production is also documented on quartzite (CALVO et al. 2015). A general feature of the Cantabrian region is therefore the documented primary unidirectional reduction of prismatic and pyramidal cores for laminar production (DE LA PEÑA 2012; CALVO et al. 2015).

Bidirectional laminar reduction is also present, as in the nearby site of El Castillo (BERNALDO DE QUIRÓS et al. 2015). In Cueva Morín this pattern is more frequently documented only for the allochthonous Flysch flint (Figs. 17 and 18), explained by this raw material's bigger nodules and a more intense core trimming activity (when interpreted as maintenance). This suggests a local adaptation to the available raw material quality, a hypothesis supported by occupations at other neighbouring sites. Bidirectional production seems to be related to sites with a high availability of good raw material due to their position in the vicinity of an outcrop such as in Mugarduia sur (BARANDIARÁN et al. 2013) or a long-distance procurement pattern like in Bolinkoba (BRADTMÖLLER 2014). Cores from Cueva Morín generally exhibit a simple configuration with a striking platform shaped by one or two 
blank negatives. The percussion during laminar production was generally performed directly with a soft hammerstone. This is a similar pattern to the Gravettian sites of La Prissé (Colonge et al. 2015), Aitzbitarte III ext. (DE LA PEÑA 2012) or Bolinkoba (BRADTMÖLLER 2014) in the Western Pyrenees. Therefore, the frequency of dorsal reduction at the edge of the striking platform is also quite high. Instead, the reduction of flakes and more generally the earlier phases of decortification were achieved using a hard percussion instrument.

Some cores exhibit a regular trimming of their flanks by means of $a 0^{\circ}$ shift in striking direction. While this maintenance stage reflects in some cases the last one, it could also be interpreted as an easy method for producing some final flakes using the old reduction surface as a striking platform. This simple kind of reorganisation can also be regularly observed on flake cores and is visible on a blade core from El Castillo (Fig. 11: 3; BERNALDO DE QUIRÓS et al. 2015: 476) and several pieces from Aitzbitarte III ext. (DE LA PEÑA 2012). Blanks from different modes of platform rejuvenation and core reconfiguration are routinely observed, but are predominantly made on flint and only occasionally on non-flint raw materials. This is especially true among blanks from platform rejuvenation showing an intensive use of direct soft hammer percussion, while the other trimming blanks are more heterogeneous. Furthermore, the high-quality flint is better represented among these blanks, which could be interpreted as more intensive maintenance due to a greater importance of these specimens. This extensive core maintenance is also visible in $\mathrm{El}$ Castillo, but is barely evident in the short-term occupation of El Mirón (GONZÁLEZ MORALES AND STRAUS 2013). A second distinct strategy for obtaining small laminar blanks is evident among the carinated cores and burin cores in Level 4 . These are also present in the nearby site El CastiIlo (Levels 14 and 12).

\subsection{Patterns of human activities and mobility in Cueva Morín}

A spatially limited human occupation in a naturally sheltered place such as a cave results in a remarkable occupation history, but it also contributes to the problematic palimpsest of single events (cf. STRAUS 1979). Cueva Morín is no exception to this rule. This problem becomes obvious in Level 4 considering the large reconstructed number of artefacts (ca. 10,000 specimens from $6.5 \mathrm{~m}^{2}$ ) and the high diversity of lithic raw material. The latter could not be completely reconstructed, but even the large amounts of Flysch and Treviño flints, whose outcrops are at least $50 \mathrm{~km}$ apart, suggest different occupational events (cf. TERBERGER 1997). Therefore, a more general understanding of human activity and mobility will come from focusing on patterns instead of single events (cf. GALANIDOU 2000; BAILEY AND GALANIDOU 2009; BRADTMÖLLER 2014). Because of their favourable preservation, the lithic assemblage provides the best available cultural record in Level 4 for gaining insight on human behaviour.
While initialisation and first trimming of the raw nodules took place outside the site (or excavated area), comprehensive knapping activities and complete reduction sequences could be observed on-site. Together with the large amount of reconstructed original artefacts, these imply an intensive human occupation. Therefore, it is noteworthy that the toolkit comprises a high percentage $(47.1 \%)$ of domestic tools. Based on a functional analysis of Upper Palaeolithic lithics (Hardy 2009), one part of the Cueva Morín assemblage likely functioned as primary tools to butcher the transported animal carcasses, while other tools were used for more secondary activities like working bone, antler and wood or animal skin processing. Nonetheless, only distinct traceological work in the future can specify such functions. Classifying the functional background of the burin group (27.1\%) is also difficult, as these tools are assigned to a wide variety of activities including bone and antler processing, engraving of parietal art or laminar production (TOMÁSKOVÁ 2005). Nonetheless, while assemblages from El Castillo (Level 12 and 14) and El Mirón (128) are dominated by $80 \%$ domestic tools and the small toolkit in Altamira Level 8 yielded many projectiles (37\%), the high frequency of burins in Level 4 is remarkable. The function of these tools likely creates this pattern, but a more comprehensive classification system based on broader data from this tool class is necessary for a better understanding of the factors involved (cf. BELFER-COHEN AND GROSMAN 2007).

Based on its diversity, the lithic assemblage resembles the general pattern of a residential base camp with a wide variety of activities and longer duration occupations (BINFORD 1980; SHOTT 1986; UTHMEIER 2004). The latter scenario is also supported by the tools' uselife. Their observed on-site modification history and the occurrence of longer modification sequences generally support long-term use and a pattern of longer duration occupations in Cueva Morín. Additional reasons to favour this hypothesis are findings like perforated molluscs and red deer teeth, the bone industry (some decorated) and a decorated retoucher made of schist (ECHEGARAY AND FREEMAN 1978). An additional factor is the extensive thermal damage on the lithic assemblage, suggesting intensive use of fire hearths within the living area. This resembles what was recently uncovered in Bolinkoba Level F, an occupation classified as a residential base camp with a high degree of logistic mobility. In contrast, short-term occupations such as Amalda Level V or Cueto de la Mina Levels $\mathrm{G}$ and $\mathrm{H}$ lack hearth features (ALTUNA et al. 1990; BRADTMÖLLER 2014; BRADTMÖLLER et al. 2015B).

Although these activities occurred within the cave, it is interesting to evaluate them in the context of human interaction with the landscape and general patterns of mobility (BINFORD 1980; KELLY 1983, 1992). While human mobility is thought to be strongly influenced by general subsistence patterns (BINFORD 1980, 2001), it is of interest that in the case of Cueva Morín, the habitat of hunted prey is congruent with the cave vicinity; animals inhabiting the co- 
Phase 0

Aquisition / Testing of Raw material

Phase $1 \mathrm{~b}$

Preparation and first cortification

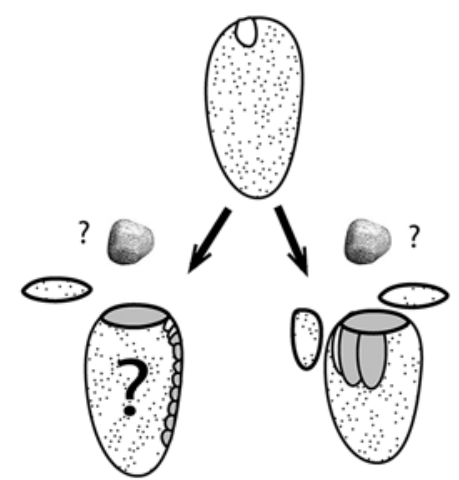

Patterns of lithic exploitation

High quality chert

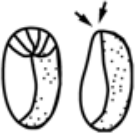

Phase 2a

Second coritfication and first production of blanks

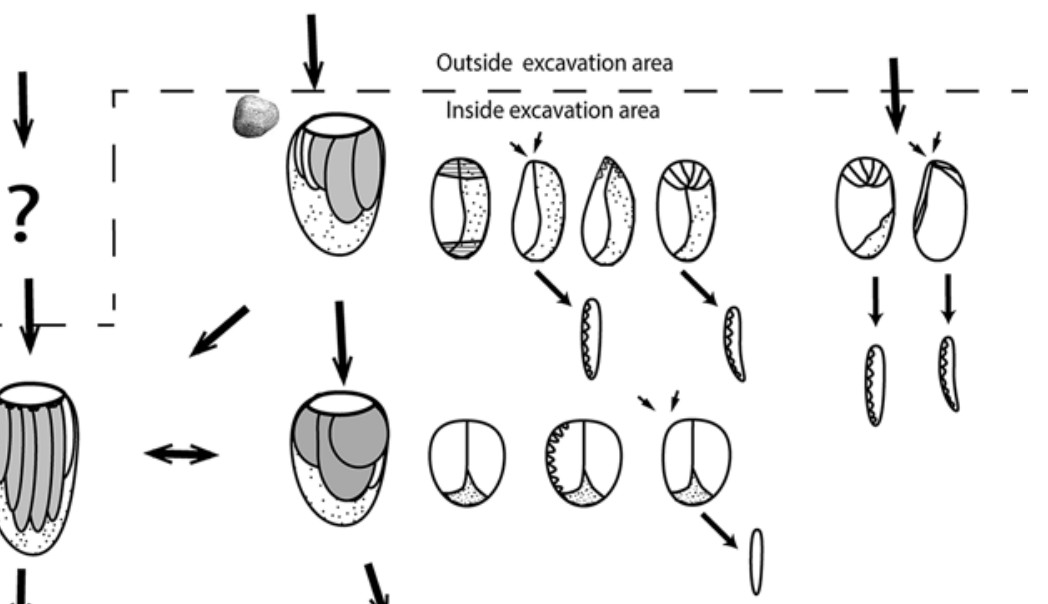

Phase 3a

Trimming

and new orientation

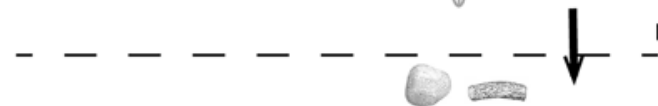

Phase 2b

Blank production

(only few pieces with cortex)
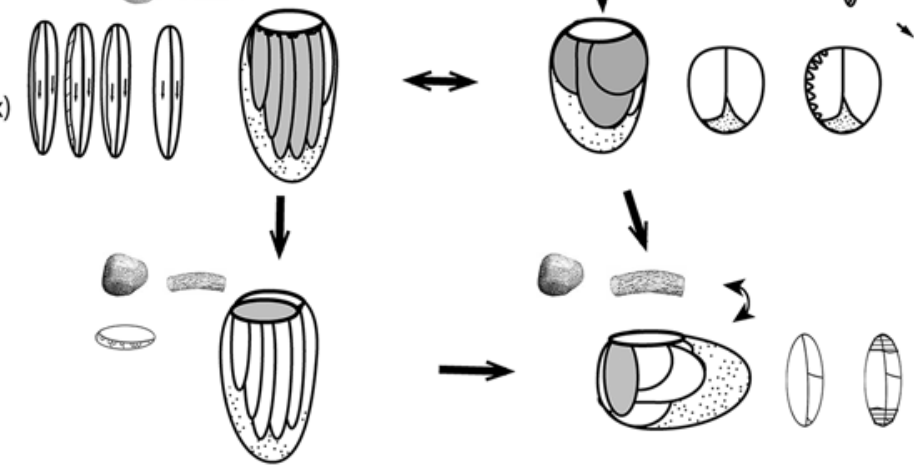

Phase 3b

Blank production
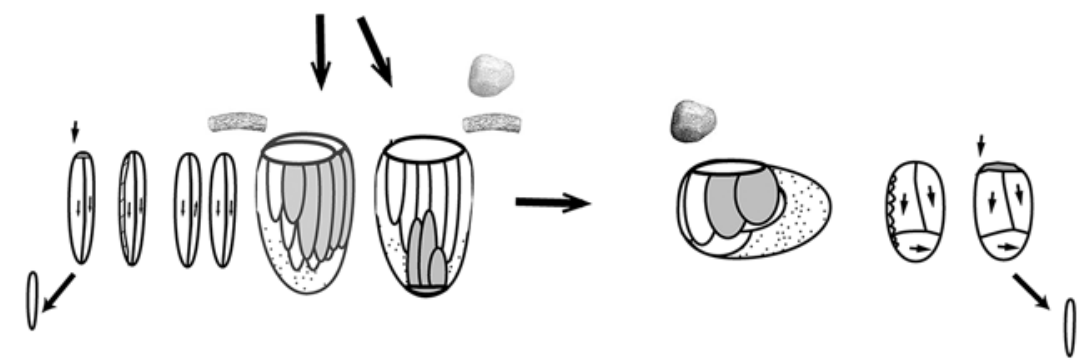

Phase 3c

Oportunistic flake production
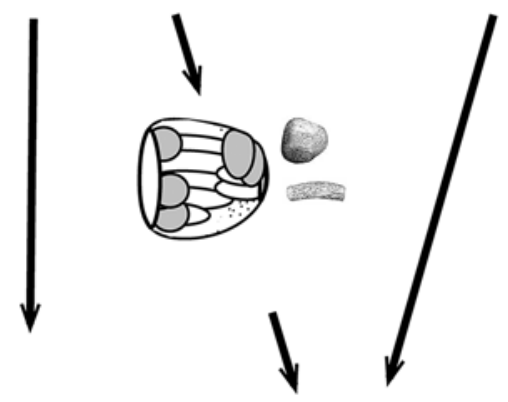

Phase 4 Export/Discard

\section{Export}

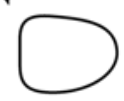

Fig. 17. Reconstructed scheme for the exploitation for high quality Flint. 
Phase 0

Aquisition / Testing of Raw material

Phase 1b

Preparation and first cortification

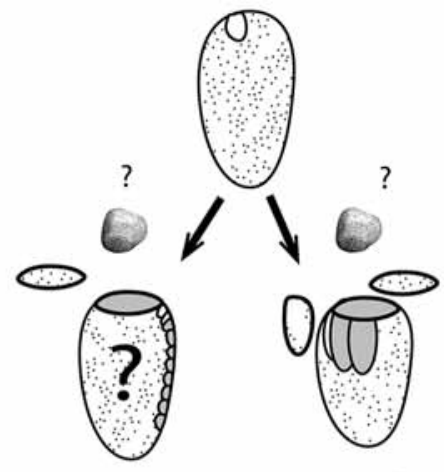

Patterns of lithic exploitation Low quality chert

Phase 2a

Second coritfication and first production of blanks (many pieces with some cortex)

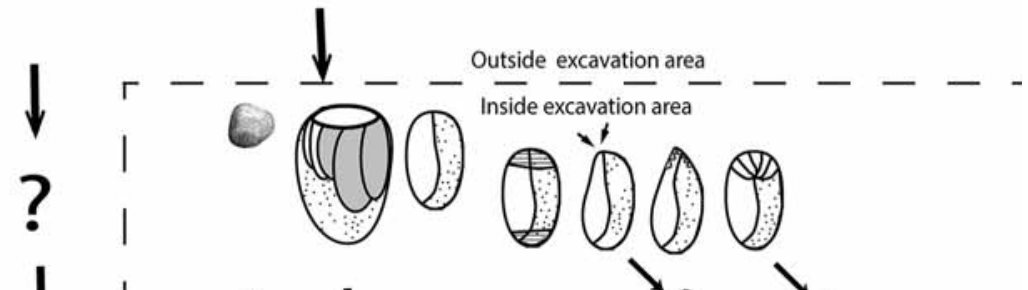

$$
-\ldots-\cdots--1
$$

Phase $2 b$

Blank production

(few pieces with cortex)
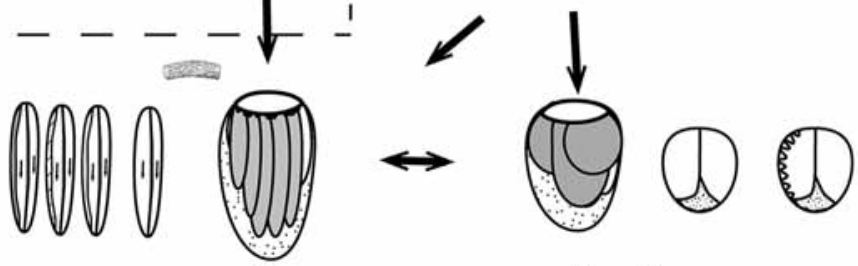<smiles>C=CC1C2CC3CC1CC(C)(C3)C2</smiles>

Phase 3a

Corrections

and new orientation
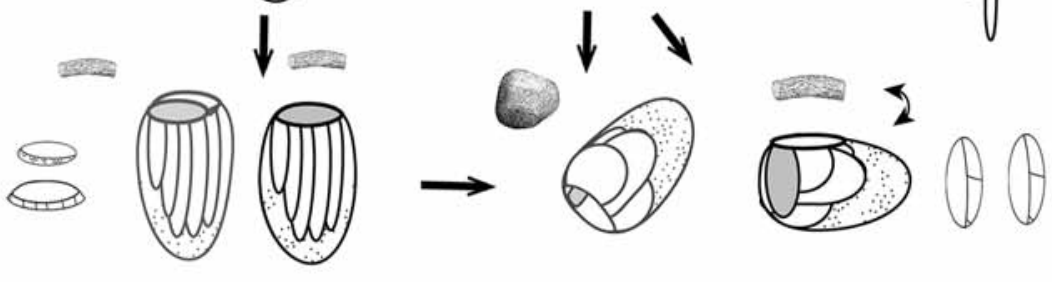

Phase 3b

Blank production
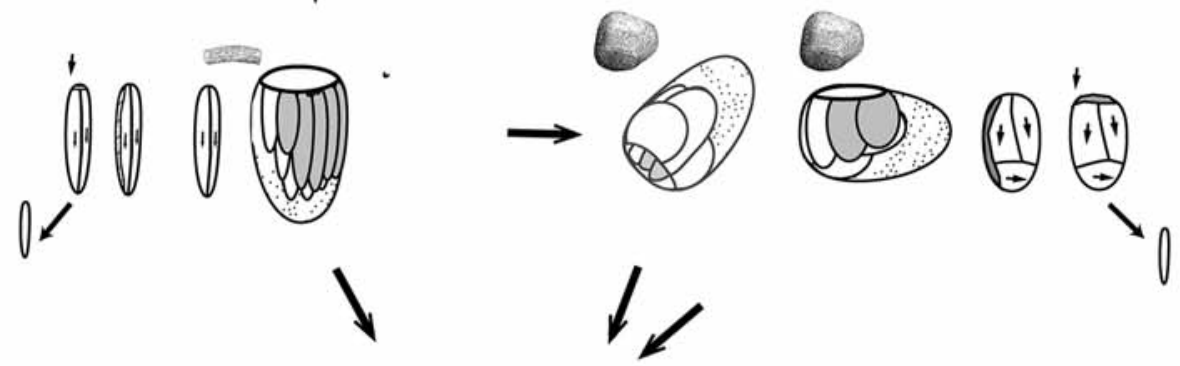

Phase 3c

Oportunistic flake production

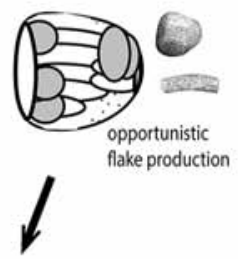

Phase 4

Discarding

Fig. 18. Reconstructed scheme for the exploitation for low/medium quality Flint. 
astal plains (Equus caballus, Bison priscus) and hill country (Cervus elaphus, Bos sp., Capreolus capreolus) comprise $81.8 \%$ of the faunal record. Based on the diversity of species, this assemblage can be classified as reflecting a nonspecialised hunting pattern (ALTUNA 1990). These hunting events likely served as opportunities to procure lithic raw material as well, as seen in the large amount of local flint, quartzite and quartz in the associated assemblage. These could be considered macro moves within a $20 \mathrm{~km}$ radius (WENIGER 1991). Regular visits to the coastal plain are also suggested by the small assemblage of littoral molluscs (ÁLVAREZ FERNÁNDEZ 2006), reflecting the regular exploitation of this resource during the Gravettian (cf. GUTIÉRREZ-ZUGASTI et al. 2013).

Furthermore, the coast likely functioned as a communication or transport route in an east-west direction. This theory is supported by the high value of Flysch flint, whose collection from long distances would constitute a macro move. Because the Flysch assemblage contains single imported artefacts as well as those reflecting the complete reduction sequence on-site, acquiring exotic raw materials can be better interpreted as logistic, rather than residential moves. A similar picture also applies to Treviño flint, even though it was found in smaller quantities. Interesting is that the combination of discarded projectiles and two burin cores perhaps reflects more extensive use of this flint for standardised laminar reduction within the hunting gear (cf. KUHN 1994), as was recently suggested for Cueto de la Mina (BRADTMÖLLER et al. 2015b).

Therefore, the high percentage of allochthonous flint in Level 4 and nearby sites suggests the great relevance of these raw materials in Cantabria, as recently stated for the Western Pyrenees (ARRIZABALAGA et al. 2014). It also points to the high level of connectivity across the entire Cantabrian region, a theory supported by comparable lithic exploitation schemes (DE LA PEÑA 2012; CALVO et al. 2015), or an unspecialised, habitat-oriented hunting strategy. Thus, the probable residential base camps (Cueva Morín, Bolinkoba, La Viña, Irikaitz, Aitzbitarte III), specialised hunting camps (Amalda, Fuente de Salín) and lithic workshops (Prado, Mugarduia sur) in the Cantabrian region together reveal a pattern characteristic for logistic mobility (BINFORD 1980). Nonetheless, with Gravettian open-air sites lacking in Cantabria (cf. ARRIZABALAGA et al. 2015) and only a limited radiocarbon dataset available, a spatial and diachronic generalisation of this situation is not yet possible.

\section{6.- CONCLUSION}

As previously stated, the Gravettian record in Cantabria and the Cantabrian region as a whole is rich and comprehensive. Nonetheless, site and artefact classification as well as a broader understanding of chronological developments or regional phenomena are difficult to achieve, at least based on the traditional study foci. The investigation of site function and human mobility can the- refore provide a different and enhanced view on this period. As demonstrated by this study and others, an enhanced analytical methodology is quite beneficial. To incorporate these local patterns within a regional settlement system and investigate the possible influence of environmental change on them (SCHMIDT et al. 2012), the actual radiocarbon dataset needs to be increased significantly; the newly provided dates presented here are only the beginning. These dates position the occupations in a relatively short timeframe between 29,040 and 28,190 cal BP, after Heinrich Event 3 and contemporaneous to Greenland Stadial 4, with nearby occupations showing a somewhat comparable age (AMS), e.g. El Castillo Level 12 ( 29 ky cal BP) and Altamira Level 8 ( 26,000 cal BP). Considering the entire Cantabrian region (including the bigger radiocarbon dataset from the eastern half), it becomes clear that the occupations represented in Level 4 occurred in the second phase of the Gravettian, with more temperate climatic conditions after the disruption of Heinrich Event 3 (IRIARTE AND MURÉLAGA 2013). This phase is actually characterised by a generally lower number of $14 \mathrm{C}$ dates, but it remains unclear if this is due to demographic phenomena, a change in the use of caves versus open-air sites or a biased dataset.

In terms of future research on these topics, analysis of lithic materials from Levels $5 a$ and $5 b$ at Cueva Morín is ongoing to follow patterns of site occupation and mobility occurring in different environmental backgrounds and cultural phases. With this study and others to come, we will have new opportunities to use the available local datasets to improve our general understanding of the currently 'non-hierarchical' Gravettian in the Cantabrian region.

\section{7.- ACKNOWLEDGEMENTS}

The lithic study of Level 4 was done within the framework of the CRC 806-Our way to Europe and a Marie Curie Fellowship of the Gerda Henkel Foundation (M4HUMAN). Aitor Calvo (University of the Basque Country) provided remarks on an early version of this paper and help concerning the microscopic classification of some raw material units. Selection and classification of the faunal sample for the $\mathrm{C} 14$ analysis were completed with the help of Marián Cueto Rapado (Autonomous University of Barcelona). José Yravedra Sainz (Universidad Complutense Madrid) contributed information about the faunal assemblage. Furthermore, the author want to thank one anonymous reviewer for their helpful annotations. The radiocarbon dates were conducted with funds from the Basque Country Research Group in Prehistory IT-622-13.

\section{BIBLIOGRAFÍA}

ABRAMOVA, Z. A.

1982 Zur Jagd im Jungpaläolithikum: nach Beispielen der jungpaläolithischen Fundplatzes Kokorevo 1 in Sibirien. Archäologisches Korrespondenzblatt 12, 1-9. 
ALTUNA

1972 Fauna de mamíferos de los yacimientos prehistóricos de Guipuzcoa. San Sebastián: Sociedad de ciencias naturales Aranzadi. Munibe XIV(1-4).

1990 La caza de herbívoros durante el Paleolítico y Mesolítico del País Vasco. Munibe Antropologia-Arkeologia 42, 229-240.

\section{ALTUNA, J., BALDEÓN, A. \& MARIEZKURRENA, K.}

1990 La cueva de Amalda (Zestoa, País Vasco). Ocupaciones paleolíticas y postpaleolíticas. San Sebastián. (Colección Barandiarán, 4).

\section{ÁLVAREZ-FERNANDEZ, E.}

2006 "Atlantic versus Mediterranean": Personal ornaments made from mollusc shells in Europe during the Upper Palaeolithic and Mesolithic in BoneCommons, Item \#462, http://alexandriaarchive.org/bonecommons/items/show/4 62 (accessed February 7, 2015).

\section{ARRIZABALAGA, Á.}

1994 Individualización morfológico de los buriles gravetienses. El "Noaillense" de Bolinkoba. Munibe Antropologia-Arkeologia 46, 33-51.

1995 La industria lítica del Paleolítico Superior inicial. Unpublished PhD thesis. University of the Basque Country. Vitoria.

\section{ARRIZABALAGA, Á. \& DE LA PEÑA, P.}

2013 El registro de la industria lítica como base para una organización del Gravetiense catábrico, in DE LAS HERAS, ARRIZABALAGA A. \& de M. LA RASILLA (ed.).: Pensando el Gravetiense: nuevos datos para la región cantábrica en su contexto peninsular y pirenaico. Rethinking the Gravettian: new approaches for the Cantabrian Region in its peninsular and pyrenean contexts. 347-368. Monografías del Museo Nacional y Centro de Investigación de Altamira. Madrid.

\section{ARRIZABALAGA, A., RIOS-GARAIZAR, J. \& ALVAREZ-ALONSO, D.}

2015 The past is out there: Open-air Palaeolithic sites and new research strategies in the Cantabrian region (northern Iberia). Quaternary of the Western Pyrenean region 364, 181-187.

BAILEY, G. \& GALANIDOU, N.

2009 Caves, palimpsests and dwelling spaces: examples from the Upper Palaeolithic of south-east Europe. World Archaeology 41 (2), 215-241.

\section{BALDEÓN, A.}

1990 Las industrias de los niveles paleolíticos, in ALTUNA, J., BALDEÓN, A. \& MARIEZKURRENA, K. (ed.).: La cueva de Amalda (Zestoa, País Vasco). Ocupaciones paleolíticas y postpaleolíticas. 63-115. Colección Barandiarán, 4. San Sebastián.

\section{BARANDIARÁN, I., CAVA, A. \& AGUIRRE, M.}

2013 El taller de sílex de Mugarduia Sur. Una ocupación de Urbasa (Navarra) durante el Gravetiense. Vitoria-Gasteiz: Universidad del País Vasco Servicio Editorial / Euskal Herriko Unibertsitatea Argitalpen Zerbitzua. Vitoria-Gasteiz.
BAUCHE, W.

1987 Untersuchung zur Steingerät- Grundformproduktion der Kulturschichtenfolge vom Zigeunerfels und der JägerhausHöhle. Unplublished Magisterarbeit. University of Cologne.

\section{BELFER-COHEN, A. \& GROSMAN, L.}

2007 Tools or cores? And why does it matter: Carinated artefacts, in Levantine Late Upper Paleolithic Assemblages. Artefacts, in MACPHERRON, S. (ed.).: Tools versus cores. Alternative approaches to stone tool analysis. 143-163. Cambridge Scholars Pub. Newcastle.

\section{BERNALDO DE QUIRÓS, F.}

1982 Los inicios del Paleolitico Superior Cantábrico. Ministerio de Cultura Dirección General de Bellas Artes y Archivos. Madrid.

BERNALDO DE QUIRÓS, F., MAÍLLO-FERNÁNDEZ, J.-M., CASTAÑOS, P. \& NEIRA, A.

2015 The Gravettian of El Castillo revisited (Cantabria, Spain). World of Gravettian Hunters. Quaternary International 359-360, 462-478.

\section{BINFORD, L.}

1980 Willow Smoke and Dogs' Tails: Hunter-Gatherer Settlement Systems and Archaeological Site Formation. American Antiquity 45 (1), 4-20.

2001 Constructing frames of reference. An analytical method for archaeological theory building using hunter-gatherer and environmental data sets. University of California Press. Berkeley.

\section{BRADTMÖLLER, M}

2013 Step by step: A new model for analysing and understanding tool type variation within and between lithic assemblages, in PASTOORS, A. \& AUFFERMANN, B. (ed.).: Pleistocene foragers: their culture and environment. Festschrift in honour of Gerd-Christian Weniger for his sixteen birthday. 225-236. Mettman.

2014 Höhlenlager des Gravettien. Muster jungpaläolithischer Höhlennutzung am Beispiel des Gravettien Nordspaniens. Verlag Dr. Kovac, Dr. Verlag (Schriften zur Ur- und Frühgeschichte, 1). Hamburg.

BRADTMÖLLER, M., ARRIZABALAGA, Á., CALVO, A., IRIARTECHIAPUSSO, M. J. \& de LA PEÑA, P.

2015a From Upper Perigordian to current Non-hierarchical Gravettian in Cantabrian Region (Northern Spain). Recent changes, current challenges, in: Forgotten Times and Spaces. New perspectives in paleoanthropological, palaeontological and archaeological studies. Vyd. 1. Masarykova universitza. Brno.

BRADTMÖLLER, M., MARREIROS, J., PEREIRA, T. \& BICHO, N.:

2015b Lithic technological adaptation within the Gravettian of the Iberian Atlantic coast: Results from two case studies. Quaternary International, doi:10.1016/j.quaint.2015.08.075.

BRADTMÖLLER, M., PASTOORS, A., WENINGER, B. \& WENIGER, G.-C.

2012 The repeated replacement model Rapid climate change and population dynamics in Late Pleistocene Europe. Quaternary International 247, 38-49. 
BREUIL, $\mathrm{H}$.

1912 Les subdivisions du Paléolithique supérieur et leur signification, in Congress International d'Anthropologie et d'Archéologie Prehistorique. 165-223. Genève.

BUTZER, K. W.

1981 Cave sediments, Upper Pleistocene stratigraphy and Mousterian facies in Cantabrian Spain. Journal of Archaeological Science 8, 133-183.

CALVO, A., FERNÁNDEZ, L., ARRIZABALAGA, Á. \& BRADTMÖLLER, $M$

2015 The lithic cultural variability during the Gravettian in the Cantabrian Region and Western Pyrenees: current state of knowledge. Quaternary International.

CARBALLO, J.

1923 Excavaciones en la Cueva del Rey, en Villanueva (Santander). Memoria. Junta Superior de Excavaciones y Antigèuedades. Madrid.

\section{CASTAÑOS, P. \& ÁLVAREZ-FERNÁNDEZ, E.}

2013 Nuevas aportaciones a las bases de subsistencia de origen animal durante el Gravetiense cantábrico, in DE LAS HERAS, ARRIZABALAGA A. \& de M. LA RASILLA (ed.) Pensando el Gravetiense: nuevos datos para la región cantábrica en su contexto peninsular y pirenaico. Rethinking the Gravettian: new approaches for the Cantabrian Region in its peninsular and pyrenean contexts, 313-329. Monografías del Museo Nacional y Centro de Investigación de Altamira. Madrid.

CAVA, A., ELORRIETA, I. \& BARANDIARÁN, I

2009 El Gravetiense de la cueva de Alkerdi (Urdax, Navarra): análisis y contexto de su industria lítica. Munibe Antropologia-Arkeologia 60, 51-80.

COLONGE, D., CLAUD, E., DESCHAMPS, M., FOURLOUBEY, C., HERNANDEZ, M. \& SELLAMI, F.

2015 Preliminary results from new Palaeolithic open-air sites near Bayonne (southwestern France). Quaternary of the Western Pyrenean region. Quaternary International 364,109-125.

\section{DE LA PEÑA, $P$.}

2009 Revisión crítica de los conjuntos líticos gravetienses y su contexto arqueológico en la Península lbérica. Complutum 20, 29-53.

2011 Sobre la identificación macroscópica de las piezas astilladas: propuesta experimental. Trabajos de Prehistoria 68, 79-98.

2012 Sobre la unidad tecnológica del Gravetiense en La Peninsula Ibérica: Implicaciones para el conocimiento de paleolitico superior inicial. http://eprints.ucm.es/16630/

2013 The palaeoclimatic record for the gravettian in the iberian peninsular. In: PASTOORS, A. \& AUFFERMANN, B. (ed.).: Pleistocene foragers: their culture and environment. Festschrift in honour of Gerd-Christian Weniger for his sixteen birthday. 183-200. Mettman.

DE LAS HERAS, C. de, MONTES, R. \& LASHERAS, J. A

2013 Altamira: nivel gravetiense y cronología de su arte rupestre, in DE LAS HERAS, ARRIZABALAGA A. \& de M. LA RASILLA (ed.).: Pensando el Gravetiense: nuevos datos para la región cantábrica en su contexto peninsular y pirenaico. Rethinking the Gravettian: new approaches for the Cantabrian Region in its peninsular and pyrenean contexts. 476-491. Monografías del Museo Nacional y Centro de Investigación de Altamira. Madrid.

DIBBLE, H.

1987 The interpretation of Middle paleolithic scraper morphology. American Antiquity 52, 109-117.

DRAFEHN, A., BRADTMÖLLER, M. \& MISCHKA, D.

2008 SDS - Systematische und digitale Erfassung von Steinartefakter. Journal of Neolithic Archaeology 16, 63-95.

ECHEGARAY, J. G. \& FREEMAN, L. G.

1971 Cueva Morín. Excavaciones 1966-1968. Patronato de las Cuevas Prehistóricas (Santander). Santander. Patronato de las Cuevas Prehistóricas (Publicaciones del Patronato de las Cuevas Prehistâoricas de la Provincia de Santander, 6). Santander.

1978 Vida y muerte en Cueva Morín. Santander. Institución Cultural de Cantabria (Colección de bolsillo, 7). Santander.

FOUCHER, P., SAN JUAN-FOUCHER, C., SACCHI, D. \& ARRIZABALAGA, Ä.

2008 Le Gravettien des Pyrénées. Paléo 20, 331-353.

GALANIDOU, N.

2000 Patterns in Caves: Foragers, Horticulturists, and the Use of Space. Journal of Anthropological Archaeology 19, 243-275.

GONZÁLEZ MORALES, M. R. \& STRAUS, L. G.

2013 La ocupación gravetiense de la cueva de El Mirón (Ramales de la Victoria, Cantabria) y el contexto del arte paleolítico temprano de la cuenca del Asón, in DE LAS HERAS, ARRIZABALAGA A. \& de M. LA RASILLA (ed.).: Pensando el Gravetiense: nuevos datos para la región cantábrica en su contexto peninsular y pirenaico. Rethinking the Gravettian: new approaches for the Cantabrian Region in its peninsular and pyrenean contexts. 289-301. Monografías del Museo Nacional y Centro de Investigación de Altamira Madrid.

GUTIÉRREZ-ZUGASTI, I., CUENCA-SOLANA, D., GONZALEZ MORALES, M. \& GARCÍA MORENO, A.

2013 El aprovechamiento de moluscos y otros recursos litorales durante el Gravetiense en la región cantábrica: análisis arqueomalacológico de la cueva de la Fuente del Salín, in DE LAS HERAS, C., ARRIZABALAGA A. \& de LA RASILLA, M. (ed.).: Pensando el Gravetiense: nuevos datos para la región cantábrica en su contexto peninsular y pirenaico. Rethinking the Gravettian: new approaches for the Cantabrian Region in its peninsular and pyrenean contexts. 416-429. Monografías del Museo Nacional y Centro de Investigación de Altamira. Madrid.

HAHN, J.

1978 Erkennen und Bestimmen von Stein- und Knochenartefakten. Einführung in die Artefaktmorphologie. Tübingen.

HARTZ, S.

1999 Die Steinartefakte des endmesolithischen Fundplatzes Grube-Rosenhof. Studien an Flintinventaren aus der Zeit der Neolithisierung in Schleswig-Holstein und Südskan- 
dinavien. Verein zur Förderung des Archäologischen Landesmuseums e.V.; In Kommission bei Wachholz Verlag (Untersuchungen und Materialien zur Steinzeit in Schleswig-Holstein aus dem Archäologischen Landesmuseum der Stiftung Schleswig-Holsteinische Landesmuseen Schloss Gottorf, 2). Schleswig, Neumünster.

\section{HARDY, B.}

2009 Understanding Stone Tool Function: Methods and Examples from the Aurignacian Levels at Hohle Fels. Mitteilungen der Gesellschaft für Urgeschichte 18, 109-121.

\section{HARROLD, F.B.}

1993 Variability and Function among Gravette Points from Southwestern France, in PETERKIN, G.L., BRICKER, H.M. \& MELLARS, P. (Eds.), Hunting and animal exploitation in the later Palaeolithic and Mesolithic of Eurasia. 69-81. Archaeological papers of the American Anthropological Association 4. American Anthropological Association, Washington D.C.

\section{HERTELL, E. \& TALLAVAARA, M.}

2011 Hunter-Gatherer Mobility and the Organisation of Core Technology in Mesolithic North-Eastern Europe, in RANKAMA, T. (ed.).: Mesolithic Interfaces. Variability in Lithic Technologies in Eastern Fennoscandia. 94-110. Monographs of the Archaeological Society of Finland, Mesolithic Interfaces. Variability in Lithic Technologies in Eastern.

\section{HISCOCK, P}

1996 Transformations of Upper Palaeolithic implements in the Dabba industry from Haua Fteah (Libya). Antiquity 70, 657-664.

2002 Quantifying the Size of Artefact Assemblages. Journal of Archaeological Science, 251-258.

\section{HÖHN, B.}

1997 Das Michelsberger Erdwerk Inden 9, Gem. Jülich, Kr. Düren. In: LÜNING, J. (ed.).: Studien zur neolithischen Besiedlung der Aldenhovener Platte und ihrer Umgebung. 473-598. Rheinland-Verlag (Rheinische Ausgrabungen, 43), Köln.

INIZAN, M.-L., ROCHE, H., TIXIER, J. \& REDURON, M.

1992 Technology of knapped stone. CREP (Préhistoire de la pierre taillée, 3). Meudon.

\section{IRIARTE-CHIAPUSSO, M. J. \& MURÉLAGA, X.}

2013 El registro microfaunístico y paleobotánico en la región cantábrica durante el Gravetiense. Reconstrucción paleoambiental, in DE LAS HERAS, C., ARRIZABALAGA A. \& de M. LA RASILLA (ed.).: Pensando el Gravetiense: nuevos datos para la región cantábrica en su contexto peninsular y pirenaico. Rethinking the Gravettian: new approaches for the Cantabrian Region in its peninsular and pyrenean contexts. 302-312. Monografías del Museo Nacional y Centro de Investigación de Altamira. Madrid.

\section{KELLY, R. L.}

1983 Hunter-Gatherer Mobility Strategies. Journal of Anthropological Research 39 (3), 277-306.

1992 Mobility/Sedentism: Concepts, Archaeological Measures, and Effects. Annual Review of Anthropology 21, 43-66.
KLARIC, L.

2007 Regional groups in the European Middle Gravettian: a reconsideration of the Rayssian technology. Antiquity 81, 176-190.

KLARIC, L., GUILLERMIN, P. \& AUBRY, A. T.

2009 Des armatures variées et des modes de productions variables. Réflexions à partir de quelques exemples issus du Gravettien d'Europe occidentale (France, Portugal, Allemagne). Gallia Préhistoire 51, 113-154.

LAVILLE, H. \& HOYOS GÓMEZ, M.

1994 Algunas precisiones sobre la estratigrafía y sedimentología de cueva Morín, Santander, in BERNALDO DE QUIROS, F. (ed.).: El cuadro geocronológico del Paleolítico superior inicial. 200-209. Monografías (Museo y Centro de Investigación de Altamira, 13). Madrid.

\section{LEROI-GOURHAN, A}

1971 Análisis polínico de cueva Morín, in GONZALEZ ·ECHEGARAY, J. \& FREEMAN, L.G. (ed.):: Cueva Morín. Excavaciones 1966-1968. 359-369. Patronato de las Cuevas Prehistóricas (Publicaciones del Patronato de las Cuevas Prehistóricas de la Provincia de Santander. Santander.

MAíLLO-FERNÁNDEZ, J. M.

2002 Tecnología lítica en el Auriñaciense arcaico de Cueva Morín. Prehistoria y Arqueología, 87-116.

2005 La Producción Laminar en la chatelperroniense de Cueva Morín. Trabajos de Prehistoria 62, 47-62.

2006 La producción de lascas en el Auriñaciense arcaico de Cueva Morín (Cantabria). Sautuola XII, 45-58.

MAílLLO-FERNÁNDEZ, J. M., ARTEAGA, C., IRIARTE-CHIAPUSSO, M. J., FERNÁNDEZ, A. R. W. \& BERNALLÓ DE QUIRÓS, F.

2014 Cueva Morín, in RAMOS, R. (ed.).: Pleistocene and Holocene hunter-gatherers in Iberia and the Gibraltar strait. The current archaeological record. Universidad de Burgos. Burgos.

MARREIROS, J., BICHO, N., GIBAJA, J., PEREIRA, T. \& CASCALHEIRA, J.

2015 Lithic technology from the Gravettian of Vale Boi: new insights into Early Upper Paleolithic human behavior in Southern Iberian Peninsula. World of Gravettian Hunters. Quaternary International 359-360, 479-198.

MARTÍNEZ, L. \& SANTAMARÍA, D.

2013 El Gravetiense en Asturias: revisión y novedades, in DE LAS HERAS, C., ARRIZABALAGA A. \& DE LA RASILLA, M. (ed.).: Pensando el Gravetiense: nuevos datos para la región cantábrica en su contexto peninsular y pirenaico. Rethinking the Gravettian: new approaches for the Cantabrian Region in its peninsular and pyrenean contexts. 276-288. Monografías del Museo Nacional y Centro de Investigación de Altamira. Madrid.

MARTINEZ GARCIA, E.

1971 El Flysch Carbonifero de Pedueles (Asturias). Trabajos de Geología 3, 277-283.

MOREAU, L.

2009 Geißenklösterle. Das Gravettien der Schwäbischen Alb im europäischen Kontext. Tübingen: Kerns (Tübinger Monographien zur Urgeschichte). 
OBERMAIER, $\mathrm{H}$.

1916 El hombre fósil. Museo Nacional de Ciencias Naturales (Memoria / Comisión de Investigaciones Paleontológicas y Prehistóricas, 9). Madrid.

PASTOORS, A.

2001 Die mittelpaläolithische Freilandstation von Salzgitter-Lebenstedt: Genese der Fundstelle und Systematik der Steinbearbeitung. Ruth Printmedien (Salzgitter Forschungen, 3). Braunschweig.

PERELLÓ, E. R. \& LÓPEZ, S. R.

1990 Gravetiense y solutrense en la Península Ibérica. Espacio, Tiempo y Forma, Prehistoria y Arqueología 3, 55-70.

PESESSE, D.

2006 La «pointes à dos alternes», un nouveau fossile directeur du Gravettien? Bulletin de la Société Préhistorique Française 103(3), 465-473.

PINTO-LLONA, A., CLARK, G., BLACKWELL, B., SKINNER, A., ANDREWS, P. \& REED, K.

2012 The Sopeña Rockshelter, a New Site in Asturias (Spain) bearing evidence on the Middle and Early Upper Palaeolithic in Northern Iberia. Munibe Antropologia-Arkeologia 63, 45-79.

RICHTER, J.

1997 Sesselfelsgrotte III. Der G-Schichten Komplex der Sesselfelsgrotte. Zum Verständnis des Micoquien. Saarbrücker Dr. und Verl. (Quartär-Bibliothek, 7). Saarbrücken.

RISSETTO, J.

2009 Late Pleistocene Hunter- Gatherer Mobility Patterns and lithic exploitation in eastern Cantabria (Spain). Unpublished PhD thesis. University of New Mexico, Albuquerque.

ROTS, V. \& PLISSON, H.,

2014 Projectiles and the abuse of the use-wear method in a search for impact. Journal of Archaeological Science, 48 154-165.

SANGUINO GONZÁLEZ, J., MONTES BARQUIIN, R. \& MARTIIN BLANCO, $P$.

2005 El marco cronoestratigráfico y paleoclimático del Pleistoceno superior inicial de la región cantábrica, un gigante con pies de barro? in SANTONJA, M., PÉREZ-GONZÁLEZ, A. \& MACHADA José, M. (ed.).: Geoarqueología y patrimonio en la Península Ibérica y el entorno mediterráneo. 127-138. Almazán.

SANO, K.

2009 Hunting evidence from stone artefacts from the Magdalenian cave site Bois Laiterie, Belgium. Quartär 56, 67-86.

2012 Functional variability in the Late Upper Palaeolithic of North-Western Europe. A traceological approach. Habelt (Universitätsforschungen zur Prähistorischen Archäologie, 219). Bonn.

SANO, K. and OBA, M.

2015 Backed point experiments for identifying mechanicallydelivered armatures. Journal of Archaeological Science 63, 13-23.
SARABIA, P. M.

1999 Notas sobre los modelos de aprovisionamiento de materias primas líticas en el Paleolítico Superior de Cueva Morín (Villanueva de Villaescusa, Cantabria). Sautuola 6, 145-154.

SCHMIDT, I., BRADTMÖLLER, M., KEHL, M.; PASTOORS, A., TAFELMAIER, Y., WENINGER, B. \& WENIGER, G.-C.

2012 Rapid climate change and variability of settlement patterns in Iberia during the Late Pleistocene. Quaternary International 274, 179-204.

SCHÖN, W.

1996 Ausgrabungen im Wadi el Akhdar, Gilf Kebir (SW-Ägypten). Heinrich-Barth-Inst. (Africa praehistorica, 8). Köln.

SHOTT, M.

1986 Technological Organization and Settlement Mobility: An Ethnographic Examination. Journal of Anthropological Research 42, 15-51.

1999 On bipolar reduction and splintered pieces. North American Archaeologist 20(3), 217-238.

2002 Weibull estimation on use life distribution in experimental spear-point data. Lithic Technology 27, 93-109.

SIMONET, A.,

2011 The diversity of hunting camps in the Pyrenean Gravettian. P@lethnology 3, 183-210.

SOTO BARREIRO, M. J.

2003 Cronología radiométrica, ecología y clima del paleolítico cantábrico. Ministerio de Educación Cultura y Deporte (Monografías / Museo Nacional y Centro de Investigación de Altamira, 19). Madrid.

TALLER, A., BEYRIES, S., BOLUS, M. \& CONARD, N.J.

2012 Are the Magdalenian Backed Pieces From Hohle Fels Just Projectiles or Part of a Multifunctional Tool Kit? Mitteilungen der Gesellschaft für Urgeschichte 21, 37-54.

TARRIÑO, A

2006 El Silex en la Cuenca Vasco-Cantábrica y Pirineo Navarro. Caracterización y su aprovechamiento en la Prehistoria. Ministerio de Cultura. Secretaría General Técnica. Subdirección General de Publicaciones Información y Documentación. Madrid.

TARRIÑO, A. \& ELORRIETA, I.

2013 La explotación de los recursos abióticos durante el Gravetiense cantábrico. Primeros datos sobre el Pirineo occidental y la cuenca vasco-cantábrica, in DE LAS HERAS, ARRIZABALAGA A. \& de M. LA RASILLA (ed.).: Pensando el Gravetiense: nuevos datos para la región cantábrica en su contexto peninsular y pirenaico. Rethinking the Gravettian: new approaches for the Cantabrian Region in its peninsular and pyrenean contexts. 330-346. Monografías del Museo Nacional y Centro de Investigación de Altamira. Madrid.

TARRIÑO, A., ELORRIETA, I. \& GARCÍA-ROJAS, M.

2015 Flint as raw material in prehistoric times: Cantabrian Mountain and Western Pyrenees data. Quaternary of the Western Pyrenean region. Quaternary International 364, 94-108. 


\section{TERBERGER, T.}

1997 Die Siedlungsbefunde des Magdalénien-Fundplatzes Gönnersdorf. Konzentrationen III und IV. Steiner Verlag. Stuttgart.

\section{TOMASKOVA, S.}

2005 What is a Burin? Typology, Technology, and Interregional Comparison. Journal of Archaeological Method and Theory $12(2), 79-115$

URQUIJO, J., WENIGER, G.-C., FERNÁNDEZ, L. T. \& PASTOORS, A.

2009 Intervención Arqueología en Cueva Morín- Informe preliminar 2008. Santander.

\section{UTHMEIER, T.}

2004 Micoquien, Aurignacien und Gravettien in Bayern. Eine regionale Studie zum Übergang vom Mittel- zum Jungpaläolithikum. Archäologische Berichte, 18. Bonn.

\section{VEGA DEL SELLA, C. L. DE}

1921 El paleolítico de cueva Morín (Santander) y notas para la climatología cuaternaria. Museo Nacional de Ciencias Naturales (Memoria / Comisión de Investigaciones Paleontológicas y Prehistóricas, Junta para Ampliación de Estudios e Investigaciones Científicas, 25). Madrid.

\section{WENIGER, G.-Chr.}

1991 Überlegungen zur Mobilität jägerischer Gruppen im Jungpaläolithikum. Saeculum 42, 82-103.
WENINGER, B. \& JÖRIS, O.

2008 A 14C age calibration curve for the last 60 ka: the Greenland-Hulu U/Th timescale and its impact on understanding the Middle to Upper Paleolithic transition in Western Eurasia. Chronology of the Middle-Upper Paleolithic Transition in Eurasia 55 (5), 772-781.

WIERER, U.

2013 Variability and standardization: The early Gravettian lithic complex of Grotta Paglicci, Southern Italy. Quaternary in Italy: knowledge and perspective 288, 215-238.

\section{YRAVEDRA, J.}

2002 La subsistencia en la paleolítico superior inicial en la región mediterránea de la península Ibérica. Gallaecia 8, 45-60.

2013 New Contributions on Subsistence Practices during the Middle-Upper Paleolithic, in Northern Spain. In: CLARK, J. L. \& SPETH, J. D. (ed.).: Zooarchaeology and modern human origins. Human hunting behavior during the later Pleistocene. 77-95. Springer (Vertebrate paleobiology and paleoanthropology). Dordrecht, New York.

\section{YRAVEDRA, J. \& GÓMEZ CASTANEDO, A.}

2011 Análisis de los procesos taxonómicos de Cueva Morín. Zephyrus LXVII, 69-90. 